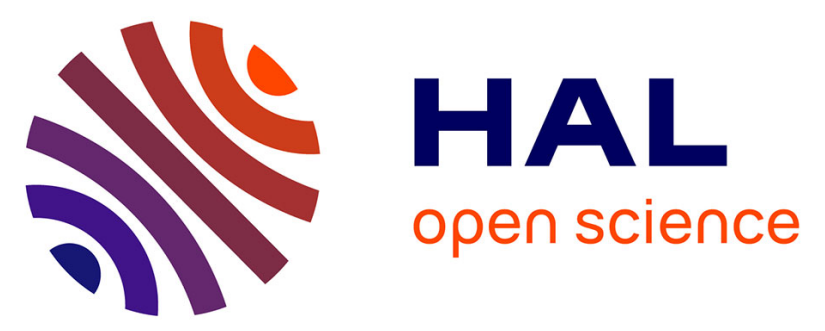

\title{
Pharmacokinetic neuroimaging to study the dose-related brain kinetics and target engagement of buprenorphine in vivo
}

\author{
Sylvain Auvity, Sébastien Goutal, Fabien Caillé, Dominique Vodovar, Alain \\ Pruvost, Catriona Wimberley, Claire Leroy, Matteo Tonietto, Michel \\ Bottlaender, Nicolas Tournier
}

\section{To cite this version:}

Sylvain Auvity, Sébastien Goutal, Fabien Caillé, Dominique Vodovar, Alain Pruvost, et al.. Pharmacokinetic neuroimaging to study the dose-related brain kinetics and target engagement of buprenorphine in vivo. Neuropsychopharmacology, 2021, 46 (6), pp.1220-1228. 10.1038/s41386-021-00976-w . cea-03215261

\section{HAL Id: cea-03215261 https://hal-cea.archives-ouvertes.fr/cea-03215261}

Submitted on 3 May 2021

HAL is a multi-disciplinary open access archive for the deposit and dissemination of scientific research documents, whether they are published or not. The documents may come from teaching and research institutions in France or abroad, or from public or private research centers.
L'archive ouverte pluridisciplinaire HAL, est destinée au dépôt et à la diffusion de documents scientifiques de niveau recherche, publiés ou non, émanant des établissements d'enseignement et de recherche français ou étrangers, des laboratoires publics ou privés. 
Pharmacokinetic neuroimaging to study the dose-related brain kinetics and target engagement of buprenorphine in vivo

Sylvain AUVITY ${ }^{1,2}$ (PhD, PharmD), Sébastien GOUTAL ${ }^{1,3}$ (MSc), Fabien CAILLÉ ${ }^{1,4}(\mathrm{PhD})$, Dominique VODOVAR ${ }^{1,2}\left(\mathrm{PhD}\right.$, MD), Alain PRUVOST ${ }^{5}(\mathrm{PhD})$, Catriona WIMBERLEY ${ }^{1,6}$ $(\mathrm{PhD})$, Claire LEROY ${ }^{1,4}(\mathrm{PhD})$, Matteo TONIETTO ${ }^{1,4}(\mathrm{PhD})$, Michel BOTTLAENDER ${ }^{1,4}(\mathrm{PhD}$, MD), Nicolas TOURNIER ${ }^{1,4}(\mathrm{PhD}$, PharmD)

1. CEA/DRF/JOLIOT/Service Hospitalier Frédéric Joliot, 91401 ORSAY France

2. UMR-S 1144, Université de Paris, 75005 PARIS France

3. MIRCen, CEA/IBFJ/DRF-JACOB/LMN, UMR CEA CNRS 9199, Université Paris Saclay, Fontenay-aux-Roses, France

4. Université Paris-Saclay, Inserm, CNRS, CEA, Laboratoire d'Imagerie Biomédicale Multimodale Paris-Saclay, 91401 Orsay

5. Service de Pharmacologie et d'Immunoanalyse (SPI), Plateforme Smart-MS, CEA, INRA, Université Paris-Saclay, 91191, Gif-sur-Yvette, France

6. Edinburgh Imaging, Queen's Medical Research Institute, University of Edinburgh, Edinburgh, UK

Corresponding author: Nicolas Tournier (PhD, PharmD)

nicolas.tournier@cea.fr

Université Paris-Saclay, CEA, CNRS, Inserm, BioMaps,

Service Hospitalier Frédéric Joliot,

4 place du général Leclerc,

91401 ORSAY France

Phone +33169867712

Fax +33169867786 


\section{Abstract (250 words)}

3 A wide range of buprenorphine doses are used for either pain management or maintenance

4 therapy in opioid addiction. The complex in vitro profile of buprenorphine, with affinity for $\mu$-,

$5 \delta$ - and $\kappa$-opioid receptors (OR), makes it difficult to predict its dose-related

6 neuropharmacology in vivo. In rats, microPET imaging and pretreatment by OR antagonists

7 were performed to assess the binding of radiolabeled buprenorphine (microdose ${ }^{11} \mathrm{C}$ -

8 buprenorphine) to OR subtypes in vivo ( $\mathrm{n}=4$ per condition). The $\mu$-selective antagonist

9 naloxonazine $(10 \mathrm{mg} / \mathrm{kg})$ and the non-selective OR-antagonist naloxone $(1 \mathrm{mg} / \mathrm{kg})$ blocked

10 the binding of ${ }^{11} \mathrm{C}$-buprenorphine while pretreatment by the $\delta$-selective (naltrindole, $3 \mathrm{mg} / \mathrm{kg}$ )

11 or the $\kappa$-selective antagonist (norbinaltorphimine, $10 \mathrm{mg} / \mathrm{kg}$ ) did not. In four macaques, PET

12 imaging and kinetic modeling enabled description of the regional brain kinetics of ${ }^{11} \mathrm{C}$ -

13 buprenorphine, co-injected with increasing doses of unlabeled buprenorphine. No saturation

14 of the brain penetration of buprenorphine was observed for doses up to $0.11 \mathrm{mg} / \mathrm{kg}$. Regional

15 differences in buprenorphine-associated receptor occupancy were observed. Analgesic 16 doses of buprenorphine $(0.003$ and $0.006 \mathrm{mg} / \mathrm{kg}$ ) respectively occupied $20 \%$ and $49 \%$ of 17 receptors in the thalamus while saturating the low but significant binding observed in cerebellum and occipital cortex. Occupancy $>90 \%$ was achieved in most brain regions with plasma concentrations $>7 \mu \mathrm{g} / \mathrm{L}$. PET data obtained after co-injection of an analgesic dose of buprenorphine $(0.003 \mathrm{mg} / \mathrm{kg})$ predicted the binding potential of microdose ${ }^{11} \mathrm{C}$ buprenorphine. This strategy could be further combined with pharmacodynamic exploration or pharmacological MRI to investigate the neuropharmacokinetics and neuroreceptor correlate, at least at $\mu-\mathrm{OR}$, of the acute effects of buprenorphine in humans. 
2 The thebaine derivative buprenorphine is a semi-synthetic opioid of the phenanthrene family

3 [1]. Low-dose buprenorphine offers potent analgesia for the treatment of moderate to severe

4 pain in patients. Compared with other opioids, buprenorphine benefits from a unique safety

5 profile, with limited risk for respiratory depression and overdose. High-dose buprenorphine is

6 therefore approved for addiction maintenance therapy in the management of opioid use

7 disorders with a growing interest in the context of the current opioid crisis [1-3].

8 In vitro, buprenorphine is one of the most affine ligand of the human $\mu$-opioid receptor ( $\mu$-OR,

$\left.9 \mathrm{~K}_{\mathrm{i}}=0.9 \mathrm{nM}\right)$ and was compared with other opioid such as naloxone $\left(\mathrm{K}_{\mathrm{i}}=14 \mathrm{nM}\right)$, morphine

$10\left(\mathrm{~K}_{\mathrm{i}}=74 \mathrm{nM}\right)$ or oxycodone $\left(\mathrm{K}_{\mathrm{i}}=780 \mathrm{nM}\right)$ in the same conditions [4,5]. In vitro, buprenorphine is

11 also far more potent than morphine at stimulating $\mu$-OR, with half-maximal effective

12 concentration $\left(E_{50}\right)<0.1 \mathrm{nM}$ and $130 \mathrm{nM}$ for buprenorphine and morphine, respectively,

13 although buprenorphine shows lower maximum efficacy than morphine in mediating $\mu$-OR

14 coupling [4]. Buprenorphine was therefore classified as a highly potent but partial agonist of

$15 \mu$-OR $[1,6]$. Buprenorphine shows a slow dissociation rate from $\mu$-OR, assumed to account

16 for prolonged occupancy and duration of action in vivo $[7,8]$. Buprenorphine is also described

17 as antagonist of $\kappa-O R$ and $\delta-O R$, and agonist of nociceptin/ORL-1 receptors $[9,10]$. It is

18 therefore difficult to predict the in vivo dynamics of the interaction of buprenorphine with its

19 CNS targets from this complex in vitro profile.

20 There are still discrepancies in the description of the neuropharmacology of buprenorphine 21 [9,11]. In vivo, buprenorphine benefits from limited respiratory effects at high doses [12]. A 22 "ceiling" or "inverted U-shape" analgesic dose-response has been described in animals [13]. 23 However, in patients, buprenorphine shows a dose-dependent analgesic effect similar than 24 that of full agonists [11]. Peripheral pharmacokinetics of buprenorphine is well established in 25 humans [14]. Norbuprenorphine ( $N$-dealkyl-buprenorphine) is the predominant metabolite 26 and shows negligible blood-brain barrier (BBB) penetration compared with buprenorphine 27 [15]. Its relatively short elimination half-life of $\sim 3 \mathrm{~h}$ contrasts with its prolonged duration of 28 action $[1,11,14]$, suggesting particular brain kinetics.

Pharmacological Positron Emission Tomography (PET) imaging uses target-specific 30 radioligands to capture the target engagement associated with one controlled plasma level of the investigated drug [16]. The $\mu$-OR-selective radioligand ${ }^{11} \mathrm{C}$-carfentanil [17] was used in 32 healthy volunteers and heroin-dependent patients to estimate the extent and duration of $\mu$ 33 OR occupancy associated with high-doses of buprenorphine (2-16 mg, sublingual route) [1834 20]. Data regarding receptor occupancy associated with acute administration of analgesic 35 doses of buprenorphine (0.3-0.6 mg) are still lacking. Interestingly, isotopic radiolabeling of 
1 buprenorphine is feasible [21]. This provides a unique opportunity for direct determination of 2 the brain kinetics of buprenorphine, at its site of action, a strategy named pharmacokinetic 3 imaging [22]. Moreover, pharmacological doses of buprenorphine, instead of microdose 4 usually encountered in PET studies, can be safely used to mimic the clinical situation in 5 terms of pharmacokinetics and pharmacodynamics.

6 In the present study, pharmacokinetic imaging using ${ }^{11} \mathrm{C}$-buprenorphine was performed to 7 explore the neuropharmacology of buprenorphine in vivo. Blocking experiments were 8 performed to address the binding of ${ }^{11} \mathrm{C}$-buprenorphine to $\mu$-, $\delta$ - and $\kappa$-OR in rats. ${ }^{11} \mathrm{C}$ 9 buprenorphine PET imaging was then performed in macaques to assess the regional 10 neuropharmacokinetics and receptor occupancy of buprenorphine associated with a wide 11 range of buprenorphine doses, that covers its clinical use in both analgesia and addiction 12 maintenance. 


\section{2}

\section{Material and Methods}

\section{Chemicals}

Buprenorphine hydrochloride for i.v. injection $(0.3 \mathrm{mg} / \mathrm{mL})$ was obtained from Axience (Pantin, France). Naloxone hydrochloride for i.v. injection $(0.4 \mathrm{mg} / \mathrm{mL})$ was obtained from Aguettant (Lyon, France). Naloxonazine and norbinaltorphimine were obtained from SigmaAldrich (Saint-Quentin Fallavier, France) and naltrindole from Tocris (Noyal-Chatillon sur Sèche, France). Ketamine was obtained from Virbac (Caros, France). Propofol was purchased from Fresenius laboratory (Sèvres, France). Isoflurane was obtained from Abbvie (Rungis, France). ${ }^{11} \mathrm{C}$-Buprenorphine was synthesized in-house according to the method described by Lever et al. [21] with slight modifications (see supplemental material).

\section{Animals}

All animal use procedures were in accordance with the recommendations of the European Community for the care and use of laboratory animals (2010/63/UE) and the French National Committees (French Decret 2013-118). Experimental protocols were validated by a local ethics committee for animal use (CETEA/A15-002 and A18-065) and approved by the french government. Rodent experiments were conducted in male Sprague-Dawley rats $(224 \pm 43 \mathrm{~g})$. Each rat underwent a single PET experiment. Four adult male rhesus macaques (Macaca Mulatta; $8.4 \pm 3.4 \mathrm{~kg}$ in weight during the study) were obtained from Silabe (Simian Laboratory Europe, France). A minimum interval of 2 weeks was respected between two scans in the same individual.

\section{Binding of ${ }^{11} \mathrm{C}$-buprenorphine to OR subtypes in rats}

\section{MicroPET imaging}

${ }^{11} \mathrm{C}$-buprenorphine brain PET acquisitions were performed using an Inveon microPET scanner (Siemens Medical Solutions, France). Anesthesia was induced and thereafter maintained using $3 \%$ and $1.5-2.5 \%$ isoflurane in $\mathrm{O}_{2}$, respectively. A catheter was inserted in a lateral caudal vein for intravenous (i.v.) injection of tested OR-antagonists when necessary. Microdose ${ }^{11} \mathrm{C}$-buprenorphine $(34 \pm 7 \mathrm{MBq}, 3 \pm 2 \mu \mathrm{g}$, mean molar activity at time of injection $M A_{i n j}=8.2 \pm 4.4 \mathrm{GBq} . \mu \mathrm{mol}^{-1}$ ) was then injected in the same catheter.

\section{Pharmacological challenges}

Blocking experiments were performed to investigate the binding of ${ }^{11} \mathrm{C}$-buprenorphine to different OR subtypes in the living brain ( $n=4$ per condition). PET acquisitions were performed without or after previously reported blocking conditions using the non-selective OR antagonist naloxone (1 $\mathrm{mg} / \mathrm{kg}$ i.v., $5 \mathrm{~min}$ before ${ }^{11} \mathrm{C}$-buprenorphine injection) [23], the 
selective $\mu$-OR antagonist naloxonazine $\left(10 \mathrm{mg} / \mathrm{kg}\right.$ i.v., $5 \mathrm{~min}$ before ${ }^{11} \mathrm{C}$-buprenorphine injection) [24], the selective $\mathrm{K}-\mathrm{OR}$ antagonist norbinaltorphimine $(10 \mathrm{mg} / \mathrm{kg}$ intraperitoneal injection, $30 \mathrm{~min}$ before ${ }^{11} \mathrm{C}$-buprenorphine injection) [25] and the selective $\delta$-OR antagonist natrindole (3 mg/kg i.v., 5 min before ${ }^{11} \mathrm{C}$-buprenorphine injection) [26].

Data analysis

MicroPET images were reconstructed as previously described [27]. Late brain PET images acquired $40-60 \mathrm{~min}$ after ${ }^{11} \mathrm{C}$-buprenorphine injection were coregistered to the Schiffer rat brain template using PMOD software V3.9 (PMOD Technologies, Zürich, Switzerland). Cerebellum was shown devoid of $\mu$ - and $\delta-O R$ with limited expression of $\kappa-O R$ in rats [28]. Regional uptake ratios (region/cerebellum) were calculated in baseline and blocking conditions to take any change in peripheral pharmacokinetics of ${ }^{11} \mathrm{C}$-buprenorphine into account.

\section{Target engagement of buprenorphine in macaques}

\section{Co-injection study}

Further PET experiments were performed in macaques to allow for accurate arterial blood sampling during PET acquisition. First, microdose ${ }^{11} \mathrm{C}$-buprenorphine was i.v. injected, followed by a 90 min brain PET acquisition. Then, the dose-dependent receptor occupancy associated with therapeutic doses was addressed using a co-injection strategy. Increasing doses of unlabeled buprenorphine $(0 ; 0.003 ; 0.006 ; 0.03 ; 0.06$ and $0.011 \mathrm{mg} / \mathrm{kg}$, equivalent to human doses ranging from 0 to $8 \mathrm{mg} / 70 \mathrm{~kg}, \mathrm{n}=4$ per dose) were mixed in the syringe containing microdose ${ }^{11} \mathrm{C}$-buprenorphine $(8.34 \pm 3.85 \mu \mathrm{g})$. The preparation was i.v. injected at the start of dynamic PET acquisition (90 min).

\section{Acquisition procedure}

First, each monkey underwent an anatomical T1-weighted brain MR scan using an Achieva 1.5T scanner (Philips Healthcare, Suresnes, France) under ketamine anesthesia (intramuscular injection, i.m.). PET acquisitions were performed on a HR+ Tomograph (Siemens Healthcare, Knoxville, TN, USA) in anesthetized macaques as previously described [29]. Briefly, the macaque received ketamine $(10 \mathrm{mg} / \mathrm{kg}, \quad$ i.m. $)$ to induce anesthesia. After intubation in supine position, venous catheters were inserted for radiotracer injection (sural vein), propofol infusion (sural vein) and drug injection for the displacement experiments (brachial vein). Another catheter was inserted into the femoral artery for arterial blood sampling. Macaques were positioned under the camera before administration of a 2 $\mathrm{mL}$ i.v. bolus of propofol followed by a $1 \mathrm{~mL} / \mathrm{kg} / \mathrm{h}$ i.v. infusion under oxygen ventilation. Macaques were i.v. injected with microdose ${ }^{11} \mathrm{C}$-buprenorphine $\left(241 \pm 42 \mathrm{MBq}, \mathrm{MA}_{\text {inj }}=13.5 \pm 5.1\right.$ 
$1 \mathrm{GBq} / \mu \mathrm{mol})$. Increasing doses of unlabeled buprenorphine were added to ${ }^{11} \mathrm{C}$-buprenorphine

2 microdose for the co-injection study. Physiological monitoring, including heart rate, oxygen

3 saturation $\left(\mathrm{SpO}_{2}\right)$, respiratory rate, and end-tidal $\mathrm{CO}_{2}$, was performed throughout the duration

4 of the PET scan.

5 Imaging data reconstruction and segmentation

6 A post-reconstruction method was performed on dynamic PET image for noise reduction and 7 improved spatial resolution (see supplemental material) [30,31]. PET data were then 8 analyzed using PMOD software. PET images were coregistered to corresponding T1-weigted 9 MR images for each macaque. A macaque T1-weighted MR template [32] was normalized onto individual MR images. Transformation matrices were then applied to the segmentation obtained from the template to generate time-activity curves in 12 selected brain structures.

\section{Arterial Input Function and Metabolism}

During PET acquisition, arterial blood samples $(500 \mu \mathrm{L})$ were withdrawn at selected times after radiotracer injection. Samples were centrifuged (5 min; 2,054g; $4^{\circ} \mathrm{C}$ ) and the supernatant $(200 \mu \mathrm{L})$ was gamma-counted for total plasma radioactivity. Additional plasma samples were withdrawn at $0 ; 5 ; 10 ; 15 ; 30 ; 60$ and $90 \mathrm{~min}$ to measure both i) the percentage of parent (unmetabolized) ${ }^{11} \mathrm{C}$-buprenorphine using radio-HPLC and a state-of-the-art methodology [33] and ii) the total concentration of buprenorphine in plasma using mass spectrometry, after radioactive decay. The fraction of parent ${ }^{11} \mathrm{C}$-buprenorphine in each sample was used to generate the metabolite-corrected arterial input function for pharmacokinetic modeling of each PET experiment (see supplemental material, Fig. S1).

\section{Pharmacokinetic modeling}

Kinetics of radioactivity in the brain and in plasma samples were decay-corrected and expressed as the percentage of injected dose of radioactivity per volume (\%ID.cm $\left.{ }^{-3}\right)$. Kinetic modeling was performed considering the metabolite-corrected arterial input function. The initial transfer rate of ${ }^{11} \mathrm{C}$-buprenorphine from plasma into the brain $\left(K_{1}\right)$ was estimated using the graphical plot analysis, as previously described [27] (see supplemental material, Fig. S2). The brain distribution of ${ }^{11} \mathrm{C}$-buprenorphine $\left(V_{\mathrm{T}} ; \mathrm{mL} . \mathrm{cm}^{-3}\right)$ was estimated using the Logan plot graphical method [34]. Parametric images ( $V_{T}$ unit) were generated using PMOD to display the regional brain distribution of ${ }^{11} \mathrm{C}$-buprenorphine in tested conditions (Fig. 2).

Brain data obtained with ${ }^{11} \mathrm{C}$-buprenorphine co-injected with the maximal dose of unlabeled buprenorphine $(0.11 \mathrm{mg} / \mathrm{kg})$ were used to estimate the non-specific binding of ${ }^{11} \mathrm{C}$ buprenorphine (saturation scan) and define the non-displaceable volume of distribution

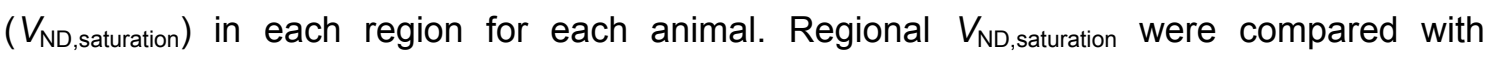




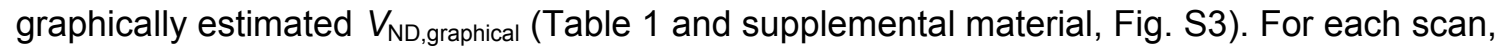
the specific binding of ${ }^{11} \mathrm{C}$-buprenorphine in each brain region was estimated as the binding potential relative to plasma $\left(\mathrm{BP}_{\mathrm{p}}\right)[35]$ with:

$$
\mathrm{BP}_{\mathrm{P}}=V_{\mathrm{T}}-V_{\mathrm{ND} \text {, saturation }}
$$

$\mathrm{BP}_{\mathrm{p}}$ estimated in microdose scans $\left(\mathrm{BP}_{\mathrm{p}, \text { microdose }}\right)$ was used to estimate the receptor occupancy associated with each pharmacological dose of unlabeled buprenorphine as follow [35]:

Receptor Occupancy $(\%)=\left(\mathrm{BP}_{\mathrm{p}, \text { microdose }}-\mathrm{BP}_{\mathrm{p}, \text { dose }}\right) / \mathrm{BP}, \mathrm{P}_{\mathrm{p}, \text { microdose }} \times 100$

The occipital cortex showed the lowest PET signal and was used as pseudo-reference tissue to estimate the regional binding of ${ }^{11} \mathrm{C}$-buprenorphine without arterial blood sampling (DVR, Logan reference method) [36]. Occipital cortex commonly serves as a reference region for quantification of PET radioligands targeting $\mu-O R$ in humans and monkeys $[18,19,37,38] . \mathrm{BP}_{\mathrm{p}}$ and DVR are unitless values.

For each region and for each scan, the receptor occupancy of ${ }^{11} \mathrm{C}$-buprenorphine was fitted to the corresponding plasma concentration of buprenorphine, measured from 60 to $90 \mathrm{~min}$ post-injection. Occupancy associated with plasma concentrations of buprenorphine obtained with the $0.11 \mathrm{mg} / \mathrm{kg}$ dose were set to $100 \%$. A non-linear fit model of saturation with one binding site was used to estimate $i)$ the plasma concentration of buprenorphine associated with regional half-maximum receptor occupancy $\left(E_{50}\right)$ and ii) the receptor occupancy associated with selected plasma levels of buprenorphine (GraphPad Prism software V7.0, San Diego, CA, USA) (see supplemental material, Fig S4, Table 1).

\section{Displacement experiments in nonhuman primates}

Additional experiments were performed to address the reversibility of ${ }^{11} \mathrm{C}$-buprenorphine binding to CNS targets. Displacement experiments were performed in 3 macaques and consisted in the injection of unlabeled buprenorphine $(0.03 \mathrm{mg} / \mathrm{kg})$ or naloxone $(0.22 \mathrm{mg} / \mathrm{kg})$, $30 \mathrm{~min}$ after ${ }^{11} \mathrm{C}$-buprenorphine injection. The selected dose of naloxone is the maximum recommended dose as an antidote against opioid overdose in humans [39]. Methods and results of displacement experiments are reported as supplemental material (Fig. S5).

\section{Statistical analysis}

Statistical comparison between conditions was performed using GraphPad Prism. Outcome parameters were compared using a 2-way ANOVA and the Tukey's post-hoc test. A result was deemed significant when a 2-tailed $p$ value was less than 0.05 . 


\section{2}

3

\section{Results}

\section{Binding of ${ }^{11} \mathrm{C}$-buprenorphine to $\mathrm{OR}$ subtypes in rats}

Baseline brain distribution of ${ }^{11} \mathrm{C}$-buprenorphine showed high PET signal in the thalamus, striatum and hypothalamus with the lowest PET signal in the cerebellum. Significant differences in uptake ratios were observed across brain regions $(p<0.001$, Fig. 1). Blocking experiments using the non-selective $\mathrm{OR}$ antagonist naloxone, used as positive control, significantly decreased ${ }^{11} \mathrm{C}$-buprenorphine binding in most brain regions, reaching similar levels than in the cerebellum ( $p>0.05)$. Blocking by the selective $\mu-O R$ antagonist naloxonazine produced similar effects than naloxone. The binding of ${ }^{11} \mathrm{C}$-buprenorphine was not significantly decreased by selective blocking of $\kappa-O R$ (norbinaltorphimine) and $\delta$-OR (naltrindole) (Fig. 1).

\section{Co-injection study in macaques}

PET images obtained in monkeys injected with microdose ${ }^{11} \mathrm{C}$-buprenorphine are shown in Fig. S6. The PET signal slowly accumulated in OR-rich regions such as the putamen, caudate and thalamus. The maximum brain concentration was $0.0255 \pm 0.0052 \% \mathrm{ID} . \mathrm{cm}^{-3}$ at $t_{\max }=22.5$ min. Regions with minimal $O R$ expression (cerebellum and occipital cortex) reached their maximum concentration earlier $\left(t_{\max }=6.6 \mathrm{~min}\right)$ with faster decrease of the radioactivity (Fig. S5).

Then, ${ }^{11} \mathrm{C}$-buprenorphine was co-injected with increasing doses of unlabeled buprenorphine up to $0.11 \mathrm{mg} / \mathrm{kg}$ (Fig. 2). Buprenorphine doses were well tolerated and no change in physiological parameters was observed. Selected doses of unlabeled buprenorphine did not impact the metabolism and plasma kinetics of ${ }^{11} \mathrm{C}$-buprenorphine with no difference in plasma exposure $(p>0.05$, Fig S1). This suggests a linear pharmacokinetics for buprenorphine in plasma within the tested dose range. The plasma concentrations of unlabeled buprenorphine estimated from 60 to $90 \mathrm{~min}$ ranged from $0.10 \pm 0.08 \mu \mathrm{g} / \mathrm{L}$ (microdose condition) to $11.56 \pm 2.94 \mu \mathrm{g} / \mathrm{L}(0.11 \mathrm{mg} / \mathrm{kg}$ condition) and were significantly correlated with injected dose (Fig. S7).

Kinetic modeling was performed to estimate ${ }^{11} \mathrm{C}$-buprenorphine distribution to brain regions in the presence of increasing doses of unlabeled buprenorphine. Co-injection of unlabeled buprenorphine up to $0.11 \mathrm{mg} / \mathrm{kg}$ did not impact the $K_{1}$ of ${ }^{11} \mathrm{C}$-buprenorphine from plasma into the brain ( $p>0.05$, Fig. S3). There was no difference in $K_{1}$ between brain regions $(p>0.05)$. Parametric mapping of $V_{T}$ obtained using microdose ${ }^{11} \mathrm{C}$-buprenorphine showed significant differences in regional $V_{T}$ between OR-rich brain regions such as the thalamus, striatal and 
1 cortical regions and OR-poor regions such as the cerebellum and occipital cortex $(p<0.01$, 2 Fig. 2).

3 The lowest dose of unlabeled buprenorphine $(0.003 \mathrm{mg} / \mathrm{kg})$ was sufficient to saturate ${ }^{11} \mathrm{C}$ buprenorphine binding in the cerebellum and occipital cortex. OR-rich regions showed a dose-dependent decrease in $V_{\mathrm{T}}$, with a maximal 2.5-fold decrease observed in the putamen obtained using the $0.06 \mathrm{mg} / \mathrm{kg}$ dose (Fig. 2). Higher dose $(0.11 \mathrm{mg} / \mathrm{kg})$ did not further decrease $V_{\mathrm{T}}$, suggesting complete saturation of buprenorphine brain targets at the 0.06 $\mathrm{mg} / \mathrm{kg}$ dose. ${ }^{11} \mathrm{C}$-buprenorphine-associated radioactivity at doses higher than $0.06 \mathrm{mg} / \mathrm{kg}$ predominantly reflected the non-specific binding of ${ }^{11} \mathrm{C}$-buprenorphine and there was no difference in regional $V_{T}$ across brain regions at either $0.06 \mathrm{mg} / \mathrm{kg}$ or $0.11 \mathrm{mg} / \mathrm{kg}(p>0.05)$. We found a strong correlation between $V_{\mathrm{ND} \text {,saturation }}$ and $V_{\mathrm{ND} \text {,graphical }}\left(\mathrm{p}<0.001, \mathrm{R}^{2}=0.997\right.$, Table 1, Fig. S3). $V_{T}$ estimated at $0.11 \mathrm{mg} / \mathrm{kg}$ therefore provides a good estimate of the regional non-displaceable volume of distribution $\left(V_{\mathrm{ND}}\right)$ of ${ }^{11} \mathrm{C}$-buprenorphine for each individual (Fig. 2).

In Figure 3, regional $V_{T}$ estimated for each dose of unlabeled buprenorphine was plotted to microdose $V_{T}$ according to the $V_{T, \text { dose }}=\mathrm{f}\left(V_{T}\right.$,microdose $)$ equation. The lowest dose of unlabeled buprenorphine $(0.003 \mathrm{mg} / \mathrm{kg})$ did not impact the slope of the equation which remained $\sim 1.0$, suggesting negligible occupancy in most brain regions. Higher doses of unlabeled buprenorphine did not further decrease $V_{T}$ in the occipital cortex and cerebellum but induced a dose-dependent decrease in the slope of the equation. Deviation of the slope from zero was not significant $(p>0.05)$ for doses of buprenorphine $\geq 0.06 \mathrm{mg} / \mathrm{kg}$, suggesting total occupancy (Fig. 3) [40].

There was a strong correlation between regional $V_{\mathrm{T}}$ and $\mathrm{BP}_{\mathrm{p}}$ obtained with ${ }^{11} \mathrm{C}$ buprenorphine $\left(R^{2}=0.98, p<0.001\right.$, Fig. 4). Thus, microdose $V_{T}$ accurately predicted the total specific binding of ${ }^{11} \mathrm{C}$-buprenorphine. $V_{\mathrm{T}}$ and $\mathrm{BP}_{\mathrm{p}}$ values estimated with kinetic modeling were used as a gold-standard to test the reliability of the Logan reference method using the occipital cortex as a pseudo-reference region [36] (Fig. 4). DVR $R_{\text {microdose }}$ and $D V R_{0.003 m g k g}$ were not significantly different ( $p>0.05$, paired $t$-test, Table 1 , Fig. 4 ), suggesting similar relative binding across brain regions. $D V R_{\text {microdose }}$ or $D V R_{0.003 m g / k g}$ correlated with $V_{T \text {,microdose }}(p<0.001$; $R^{2}=0.43$ and 0.54 , respectively, data not shown). Better correlation was found between $\mathrm{DVR}_{\text {microdose }}$ or $\mathrm{DVR}_{0.003 \mathrm{mg} / \mathrm{kg}}$ and $\mathrm{BP}_{\mathrm{p}, \text { microdose }}\left(\mathrm{p}<0.001 ; \mathrm{R}^{2}=0.64\right.$ and 0.66 , respectively). This suggests that DVR estimated using ${ }^{11} \mathrm{C}$-buprenorphine/buprenorphine at either microdose or $0.003 \mathrm{mg} / \mathrm{kg}$ predicted the regional $\mathrm{BP}_{\mathrm{p}}$ of microdose ${ }^{11} \mathrm{C}$-buprenorphine (Fig. 4).

Plasma concentrations of buprenorphine associated with analgesic doses of buprenorphine $(0.003 \mathrm{mg} / \mathrm{kg}$ and $0.006 \mathrm{mg} / \mathrm{kg}$ ) were $0.29 \pm 0.04 \mu \mathrm{g} / \mathrm{L}$ and $0.66 \pm 0.22 \mu \mathrm{g} / \mathrm{L}$, respectively (Fig. 
1 S7). In the thalamus, corresponding receptor occupancy was $20 \%$ and $49 \%$, respectively. 2 Regions with the lowest specific binding (cerebellum and occipital cortex) were fully occupied 3 at the lowest analgesic dose. Thus, poor fit and estimation of $E_{50}$ were obtained in these 4 regions (Table 1, Fig. S4). In most OR-rich regions, receptor occupancy $>90 \%$ was achieved 5 with plasma concentrations of buprenorphine $>7 \mu \mathrm{g} / \mathrm{L}$ (Table 1, Fig. S4). Regional receptor 6 occupancies associated with a range of plasma concentrations of buprenorphine were 7 estimated (Table 1). Regional differences in receptor occupancy and $\mathrm{EC}_{50}$ could be noticed. 


\section{Discussion}

PET imaging studies using $\mu$-OR-targeting radioligands are classically used for estimation of the interaction of opioids with $\mu-\mathrm{OR}$, with limited information on brain kinetics of investigated compounds [41]. Pharmacokinetic PET studies using radiolabeled analogues of drugs are increasingly used for direct determination of their BBB penetration or brain delivery [22]. This microdose strategy does not however provide information regarding pharmacodynamics, as compared with behavioral investigation or pharmacological MRI (phMRI) $[42,43]$. We used complementary pharmacokinetic neuroimaging approaches using ${ }^{11} \mathrm{C}$-buprenorphine to directly assess its binding to OR subtypes in vivo, as well as the dose-related brain kinetics and target engagement associated with clinically relevant doses of unlabeled buprenorphine.

${ }^{11} \mathrm{C}$-buprenorphine PET signal in brain regions depends on its non-specific binding, its affinity for OR subtypes, their regional availability and corresponding association/dissociation kinetics. Binding of buprenorphine to $\mu-\mathrm{OR}, \kappa-\mathrm{OR}$ and $\delta$-OR has been compared in the same in vitro conditions. Respective $\mathrm{K}_{\mathrm{i}}$ of buprenorphine for $\mu$-, $\mathrm{\kappa}$ - and $\delta$-OR was $0.08,0.44$ and $0.82 \mathrm{nM}$ (monkey), 0.08, 0.11 and $0.42 \mathrm{nM}$ (rat) and 12.4, 108 and $154 \mathrm{nM}$ (human). Buprenorphine showed much lower affinity for ORL-1 $\left(K_{i}=285 \mathrm{nM}\right.$ in rats) [9,44]. Our blocking experiments in rats suggest that the specific binding of ${ }^{11} \mathrm{C}$-buprenorphine predominantly reflects its interaction with $\mu-\mathrm{OR}$ rather than $\kappa-$ or $\delta$-OR. This is consistent with previous ex vivo data showing a single predominant high affinity binding site for ${ }^{3} \mathrm{H}$ buprenorphine in rat brain lysate, leading to linear Scatchard plot in saturation experiments [45]. Frost et al. compared the regional binding specificity of the non-selective OR antagonist ${ }^{11} \mathrm{C}$-diprenorphine and $\mu$-OR-selective agonist ${ }^{11} \mathrm{C}$-carfentanil in humans using the thalamus, a region with known predominance of $\mu-\mathrm{OR}$, as a normalization region [46]. Using the same method with our macaque data, the regional binding of ${ }^{11} \mathrm{C}$-buprenorphine obtained using either microdose or co-injection of $0.003 \mathrm{mg} / \mathrm{kg}$ of unlabeled buprenorphine fits the regional distribution of ${ }^{11} \mathrm{C}$-carfentanil rather than that of ${ }^{11} \mathrm{C}$-diprenorphine (Fig. S8, Table S1). In pharmacotherapy, the affinity for $\kappa-$ and $\delta$-OR was shown to account for the pharmacodynamics of high-dose buprenorphine [9,44]. However, from a molecular imaging perspective, only the $\mu-\mathrm{OR}$ component of the neuropharmacology of buprenorphine can be estimated using ${ }^{11} \mathrm{C}$-buprenorphine PET imaging.

Modest but significant specific binding of ${ }^{11} \mathrm{C}$-buprenorphine was observed in the cerebellum and occipital cortex in macaques, in both our co-injection and displacement experiments (Fig. S5). Data regarding the expression of OR in these brain regions in monkeys are scarce [47]. Although species differences in OR expression may exist, it was reported a low but significant local expression of $\mu$-, $\kappa$ - but not $\delta$-OR in the human cerebellum $[48,49]$. In the 
human occipital cortex, expression of $\kappa-, \delta$ - but not $\mu$-OR has been detected $[50,51]$. In other regions with known $\mu$-OR expression, unlabeled buprenorphine dose-dependently decreased ${ }^{11} \mathrm{C}$-buprenorphine $V_{\mathrm{T}}$ (Fig. 2 and 3 ). No saturation of the $\mathrm{BBB}$ penetration of ${ }^{11} \mathrm{C}$ buprenorphine was observed for doses up to $0.11 \mathrm{mg} / \mathrm{kg}$ (Fig. S2). Full saturation of neuroreceptors, achieved with the highest doses of buprenorphine, revealed the homogenous mapping of the non-specific binding of ${ }^{11} \mathrm{C}$-buprenorphine (Fig. 2). Thus, quantitative data regarding total specific binding potential of ${ }^{11} \mathrm{C}$-buprenorphine to $\mathrm{CNS}$ targets $\left(\mathrm{BP}_{\mathrm{p}}\right)$ could be derived (Table 1$)$.

Estimation of the dose-related receptor occupancy by buprenorphine using a target-specific radioligand such as ${ }^{11} \mathrm{C}$-carfentanil or ${ }^{11} \mathrm{C}$-diprenorphine may depend on the affinity of the selected probe for investigated $O R$ [52]. Direct saturation experiments with ${ }^{11} \mathrm{C}$ buprenorphine/buprenorphine therefore provide a unique in vivo translation of in vitro binding experiments [7]. Plasma levels associated with analgesic doses of buprenorphine $(0.003$ and $0.006 \mathrm{mg} / \mathrm{kg}$ ) ranged from $0.29 \pm 0.04$ to $0.66 \pm 0.22 \mu \mathrm{g} / \mathrm{L}$, consistent with clinical pharmacokinetic data in patients [14]. Corresponding plasma levels of buprenorphine occupied $<50 \%$ of the total binding in $\mu$-OR-rich regions such as the thalamus. This suggests that partial occupancy of $\mu-O R$ is sufficient to achieve effective analgesia, which may also involve action on $\kappa-O R$ and nociceptin/ORL-1 at the spinal level [53].

Buprenorphine for addiction maintenance is administered via sublingual route (bioavailability $\sim 70 \%$ ) [54]. Buprenorphine plasma levels associated with the lowest dose used for addiction maintenance $(0.03 \mathrm{mg} / \mathrm{kg})$, administered i.v., still partially occupied $\mu-O R$. Full receptor occupancy was achieved with doses $\geq 0.06 \mathrm{mg} / \mathrm{kg}$. It was suggested that $>50 \%$ of $\mu-O R$ occupancy is required to ensure suppression of withdrawal syndrome. Moreover, $\mu-O R$ occupancy $>80 \%$ is assumed to protect against opioid overdose syndrome induced by massive and unintended intake [20]. Our macaque data suggest that plasma concentrations $>7 \mu \mathrm{g} / \mathrm{L}$ have to be maintained to ensure $>90 \%$ occupancy of OR by buprenorphine in the striatum. In patients, higher doses of buprenorphine may thus essentially maintain plasma concentration over the targeted threshold to ensure sustained and effective maintenance therapy [55]. This observation is consistent with previous ${ }^{11} \mathrm{C}$-carfentanil PET data obtained in heroin-dependent subjects showing that total $\mu$-OR occupancy is prolonged by increasing the doses of buprenorphine [19].

Compared with other opioids, buprenorphine overdoses are rare but their clinical management is difficult, with poor efficacy of naloxone as antidote [56]. This is consistent with the slow reversibility of ${ }^{11} \mathrm{C}$-buprenorphine binding by high-dose naloxone $(0.22 \mathrm{mg} / \mathrm{kg})$ observed in our study. Previous blocking experiments performed in macaques and using the 
$1 \mu$-OR-selective radioligand ${ }^{11} \mathrm{C}$-carfentanil showed that $\sim 85 \%$ occupancy of $\mu$-OR was

2 achieved by a lower dose of naloxone (0.03 mg/kg, i.v., $10 \mathrm{~min}$ before PET) [38].

3 The occipital cortex and cerebellum are not proper reference tissue for ${ }^{11} \mathrm{C}$-buprenorphine 4 because of low but significant specific binding was found in these regions. We nonetheless 5 evaluated the occipital cortex as a pseudo-reference tissue region to non-invasively estimate $6 \quad{ }^{11} \mathrm{C}$-buprenorphine binding. Both $\mathrm{DVR}_{\text {microdose }}$ and $\mathrm{DVR}_{0.003 \mathrm{mg} / \mathrm{kg}}$ similarly predicted microdose $7 \quad \mathrm{BP}_{\mathrm{p}}$ (Fig. 4). In the absence of arterial input function, the binding potential of ${ }^{11} \mathrm{C}$ 8 buprenorphine in brain regions, which mainly reflects baseline availability of $\mu$-OR, can 9 therefore be estimated using either microdose or low-dose ${ }^{11} \mathrm{C}$-buprenorphine pharmacokinetic imaging using this simplified method.

11 For safety reasons, PET imaging is usually performed using microdose receptor antagonists and low injected mass to avoid any adverse effects. In radiotracer development, co-injection of radiotracers with pharmacological doses of corresponding unlabeled compounds is only used to investigate the specific binding to brain regions [57]. We assume this strategy will gain interest for multimodal pharmacological imaging protocols on simultaneous hybrid PETMR systems [58]. Using CNS-active dose, the time-course of PET-derived target engagement can therefore be directly compared with the hemodynamic response assessed using pharmacological MRI (phMRI) or other pharmacodynamic parameters in the same individual [59]. Interestingly, the CNS effects of investigated doses of buprenorphine have been studied using phMRI in both monkeys $(0.03 \mathrm{mg} / \mathrm{kg})[60]$ and humans $(0.003 \mathrm{mg} / \mathrm{kg})$ [42]. In rhesus monkeys, buprenorphine increased the cerebral blood volume in brain regions consistent with the binding of corresponding doses of buprenorphine to brain regions found in our study [60].

\section{Conclusion}

Pharmacokinetic imaging provides a pragmatic method to explore the neuropharmacokinetic and the $\mu$-OR correlates of the CNS effects of buprenorphine. ${ }^{11} \mathrm{C}$-buprenorphine co-injected with low dose buprenorphine could be safely performed as a dual-modality imaging biomarker for PET/phMRI studies. This strategy may be useful to explore variability in neurovascular coupling associated with the acute response to buprenorphine in future multimodal pharmacological studies. 


\section{Funding and Disclosure}

2 This work was performed on a platform member of France Life Imaging network (grant ANR-

3 11-INBS-0006) and was funded by the "Lidex-PIM" project funded by the IDEX Paris-Saclay,

4 ANR-11-IDEX-0003-02. There is no conflict of interest to disclose.

5

\section{Acknowledgements}

7 We gratefully thank Jérôme Cayla, Vincent Brulon and Maud Goislard for technical 8 assistance.

9

Author contribution

SA, MB, DV and NT contributed to conception of the work, data analysis and manuscript

12 writing. SA, SG and AP contributed to data acquisition. CW, MT and CL helped for PET and 13 MR imaging analysis. FC performed radiochemistry.

Supplementary information

16 Supplemental material accompanies this paper at (https://doi.org/). 


\section{References}

1. Trescot AM, Datta $S$, Lee M, Hansen H. Opioid pharmacology. Pain Physician. 2008;11:S133-153.

2. Helm S, Trescot AM, Colson J, Sehgal N, Silverman S. Opioid antagonists, partial agonists, and agonists/antagonists: the role of office-based detoxification. Pain Physician. 2008;11:225-235.

3. Wakeman SE, Barnett ML. Primary Care and the Opioid-Overdose Crisis Buprenorphine Myths and Realities. N Engl J Med. 2018;379:1-4.

4. Olson KM, Duron DI, Womer D, Fell R, Streicher JM. Comprehensive molecular pharmacology screening reveals potential new receptor interactions for clinically relevant opioids. PloS One. 2019;14:e0217371.

5. Volpe DA, McMahon Tobin GA, Mellon RD, Katki AG, Parker RJ, Colatsky T, et al. Uniform assessment and ranking of opioid $\mu$ receptor binding constants for selected opioid drugs. Regul Toxicol Pharmacol. 2011;59:385-390.

6. Virk MS, Arttamangkul S, Birdsong WT, Williams JT. Buprenorphine is a weak partial agonist that inhibits opioid receptor desensitization. J Neurosci. 2009;29:7341-7348.

7. Boas RA, Villiger JW. Clinical actions of fentanyl and buprenorphine. The significance of receptor binding. Br J Anaesth. 1985;57:192-196.

8. Bidlack JM, Knapp BI, Deaver DR, Plotnikava M, Arnelle D, Wonsey AM, et al. In Vitro Pharmacological Characterization of Buprenorphine, Samidorphan, and Combinations Being Developed as an Adjunctive Treatment of Major Depressive Disorder. J Pharmacol Exp Ther. 2018;367:267-281.

9. Lutfy K, Cowan A. Buprenorphine: a unique drug with complex pharmacology. Curr Neuropharmacol. 2004;2:395-402.

10. Cami-Kobeci G, Polgar WE, Khroyan TV, Toll L, Husbands SM. Structural determinants of opioid and NOP receptor activity in derivatives of buprenorphine. J Med Chem. 2011;54:6531-6537.

11. Raffa RB, Haidery M, Huang H-M, Kalladeen K, Lockstein DE, Ono H, et al. The clinical analgesic efficacy of buprenorphine. J Clin Pharm Ther. 2014;39:577-583.

12. Walsh SL, Preston KL, Stitzer ML, Cone EJ, Bigelow GE. Clinical pharmacology of buprenorphine: ceiling effects at high doses. Clin Pharmacol Ther. 1994;55:569-580.

13. Calabrese EJ. Pain and u-shaped dose responses: occurrence, mechanisms, and clinical implications. Crit Rev Toxicol. 2008;38:579-590.

14. Bullingham RE, McQuay HJ, Moore A, Bennett MR. Buprenorphine kinetics. Clin Pharmacol Ther. 1980;28:667-672.

15. Auvity S, Breuil L, Goislard M, Bottlaender M, Kuhnast B, Tournier N, et al. An original radio-biomimetic approach to synthesize radiometabolites for PET imaging. Nucl Med Biol. 2020:S0969805120301888.

16. Suridjan I, Comley RA, Rabiner EA. The application of positron emission tomography (PET) imaging in CNS drug development. Brain Imaging Behav. 2019;13:354-365.

17. Nummenmaa L, Karjalainen $T$, Isojärvi J, Kantonen $T$, Tuisku J, Kaasinen V, et al. Lowered endogenous mu-opioid receptor availability in subclinical depression and anxiety. Neuropsychopharmacol. 2020. 30 May 2020. https://doi.org/10.1038/s41386020-0725-9.

18. Zubieta J, Greenwald MK, Lombardi U, Woods JH, Kilbourn MR, Jewett DM, et al. Buprenorphine-induced changes in mu-opioid receptor availability in male heroindependent volunteers: a preliminary study. Neuropsychopharmacol. 2000;23:326-334.

19. Greenwald MK, Johanson C-E, Moody DE, Woods JH, Kilbourn MR, Koeppe RA, et al. Effects of buprenorphine maintenance dose on mu-opioid receptor availability, plasma concentrations, and antagonist blockade in heroin-dependent volunteers. Neuropsychopharmacol. 2003;28:2000-2009.

20. Greenwald MK, Comer SD, Fiellin DA. Buprenorphine maintenance and mu-opioid receptor availability in the treatment of opioid use disorder: implications for clinical use and policy. Drug Alcohol Depend. 2014;144:1-11. 
21. Lever JR, Mazza SM, Dannals RF, Ravert HT, Wilson AA, Wagner HN. Facile synthesis of [11C]buprenorphine for positron emission tomographic studies of opioid receptors. Int J Rad Appl Instrum [A]. 1990;41:745-752.

22. Tournier N, Stieger B, Langer O. Imaging techniques to study drug transporter function in vivo. Pharmacol Ther. 2018;189:104-122.

23. Ott J, Spilhaug MM, Maschauer S, Rafique W, Jakobsson JE, Hartvig K, et al. Pharmacological Characterization of Low-to-Moderate Affinity Opioid Receptor Agonists and Brain Imaging with 18F-Labeled Derivatives in Rats. J Med Chem. 2020;63:94849499.

24. Chevillard L, Mégarbane B, Risède P, Baud FJ. Characteristics and comparative severity of respiratory response to toxic doses of fentanyl, methadone, morphine, and buprenorphine in rats. Toxicol Lett. 2009;191:327-340.

25. Placzek MS, Schroeder FA, Che T, Wey H-Y, Neelamegam R, Wang C, et al. Discrepancies in Kappa Opioid Agonist Binding Revealed through PET Imaging. ACS Chem Neurosci. 2019;10:384-395.

26. Poisnel G, Oueslati F, Dhilly M, Delamare J, Perrio C, Debruyne D, et al. [11C]MeJDTic: a novel radioligand for kappa-opioid receptor positron emission tomography imaging. Nucl Med Biol. 2008;35:561-569.

27. Auvity S, Chapy H, Goutal S, Caillé F, Hosten B, Smirnova M, et al. Diphenhydramine as a selective probe to study $\mathrm{H}$-antiporter function at the blood-brain barrier: Application to [11C]diphenhydramine positron emission tomography imaging. J Cereb Blood Flow Metab. 2017;37:2185-2195.

28. Tempel A, Zukin RS. Neuroanatomical patterns of the mu, delta, and kappa opioid receptors of rat brain as determined by quantitative in vitro autoradiography. Proc Natl Acad Sci. 1987;84:4308-4312.

29. Tournier N, Goutal S, Auvity S, Traxl A, Mairinger S, Wanek T, et al. Strategies to Inhibit ABCB1- and ABCG2-Mediated Efflux Transport of Erlotinib at the Blood-Brain Barrier: A PET Study on Nonhuman Primates. J Nucl Med. 2017;58:117-122.

30. Auvity S, Tonietto M, Caillé F, Bodini B, Bottlaender M, Tournier N, et al. Repurposing radiotracers for myelin imaging: a study comparing 18F-florbetaben, 18F-florbetapir, 18F-flutemetamol,11C-MeDAS, and 11C-PiB. Eur $\mathrm{J}$ Nucl Med Mol Imaging. 2020;47:490-501.

31. Reilhac A, Charil A, Wimberley C, Angelis G, Hamze H, Callaghan P, et al. 4D PET iterative deconvolution with spatiotemporal regularization for quantitative dynamic PET imaging. Neurolmage. 2015;118:484-493.

32. Rohlfing T, Kroenke CD, Sullivan EV, Dubach MF, Bowden DM, Grant KA, et al. The INIA19 Template and NeuroMaps Atlas for Primate Brain Image Parcellation and Spatial Normalization. Front Neuroinformatics. 2012;6:27.

33. Bentourkia M. Determination of the Input Function at the Entry of the Tissue of Interest and Its Impact on PET Kinetic Modeling Parameters. Mol Imaging Biol. 2015;17:748756.

34. Logan J, Fowler JS, Volkow ND, Wolf AP, Dewey SL, Schlyer DJ, et al. Graphical analysis of reversible radioligand binding from time-activity measurements applied to [N-11C-methyl]-(-)-cocaine PET studies in human subjects. J Cereb Blood Flow Metab. 1990;10:740-747.

35. Martinez D, Hwang D, Mawlawi O, Slifstein M, Kent J, Simpson N, et al. Differential occupancy of somatodendritic and postsynaptic $5 \mathrm{HT}(1 \mathrm{~A})$ receptors by pindolol: a doseoccupancy study with [11C]WAY 100635 and positron emission tomography in humans. Neuropsychopharmacol. 2001;24:209-229.

36. Logan J, Fowler JS, Volkow ND, Wang GJ, Ding YS, Alexoff DL. Distribution volume ratios without blood sampling from graphical analysis of PET data. J Cereb Blood Flow Metab. 1996;16:834-840.

37. Frost JJ, Douglass KH, Mayberg HS, Dannals RF, Links JM, Wilson AA, et al. Multicompartmental analysis of [11C]-carfentanil binding to opiate receptors in humans 
measured by positron emission tomography. J Cereb Blood Flow Metab. 1989;9:398409.

38. Saccone PA, Lindsey AM, Koeppe RA, Zelenock KA, Shao X, Sherman $P$, et al. Intranasal Opioid Administration in Rhesus Monkeys: PET Imaging and Antinociception. J Pharmacol Exp Ther. 2016;359:366-373.

39. Boyer EW. Management of opioid analgesic overdose. N Engl J Med. 2012;367:146155.

40. Cunningham VJ, Rabiner EA, Slifstein M, Laruelle M, Gunn RN. Measuring drug occupancy in the absence of a reference region: the Lassen plot re-visited. J Cereb Blood Flow Metab. 2010;30:46-50.

41. Henriksen G, Willoch F. Imaging of opioid receptors in the central nervous system. Brain. 2008;131:1171-1196.

42. Upadhyay J, Anderson J, Schwarz AJ, Coimbra A, Baumgartner R, Pendse G, et al. Imaging drugs with and without clinical analgesic efficacy. Neuropsychopharmacol. 2011;36:2659-2673.

43. Jenkins BG. Pharmacologic magnetic resonance imaging (phMRI): Imaging drug action in the brain. Neurolmage. 2012;62:1072-1085.

44. Ide S, Minami M, Satoh M, Uhl GR, Sora I, Ikeda K. Buprenorphine antinociception is abolished, but naloxone-sensitive reward is retained, in mu-opioid receptor knockout mice. Neuropsychopharmacol. 2004;29:1656-1663.

45. Villiger JW, Taylor KM. Buprenorphine: characteristics of binding sites in the rat central nervous system. Life Sci. 1981;29:2699-2708.

46. Frost JJ, Mayberg HS, Sadzot B, Dannals RF, Lever JR, Ravert HT, et al. Comparison of [11C]diprenorphine and [11C]carfentanil binding to opiate receptors in humans by positron emission tomography. J Cereb Blood Flow Metab. 1990;10:484-492.

47. Ragen BJ, Freeman SM, Laredo SA, Mendoza SP, Bales KL. $\mu$ and $\mathrm{k}$ opioid receptor distribution in the monogamous titi monkey (Callicebus cupreus): implications for social behavior and endocrine functioning. Neuroscience. 2015;290:421-434.

48. Schadrack J, Willoch F, Platzer S, Bartenstein P, Mahal B, Dworzak D, et al. Opioid receptors in the human cerebellum: evidence from [11C]diprenorphine PET, mRNA expression and autoradiography. Neuroreport. 1999;10:619-624.

49. Hammers A, Lingford-Hughes A. Opioid imaging. Neuroimaging Clin N Am. 2006;16:529-552, vii.

50. Hiller JM, Fan LQ. Laminar distribution of the multiple opioid receptors in the human cerebral cortex. Neurochem Res. 1996;21:1333-1345.

51. Valentino RJ, Volkow ND. Untangling the complexity of opioid receptor function. Neuropsychopharmacol. 2018;43:2514-2520.

52. Hume SP, Lingford-Hughes AR, Nataf V, Hirani E, Ahmad R, Davies AN, et al. Low sensitivity of the positron emission tomography ligand [11C]diprenorphine to agonist opiates. J Pharmacol Exp Ther. 2007;322:661-667.

53. Gudin J, Fudin J. A Narrative Pharmacological Review of Buprenorphine: A Unique Opioid for the Treatment of Chronic Pain. Pain Ther. 2020. 28 January 2020. https://doi.org/10.1007/s40122-019-00143-6.

54. Bullingham RE, McQuay HJ, Porter EJ, Allen MC, Moore RA. Sublingual buprenorphine used postoperatively: ten hour plasma drug concentration analysis. $\mathrm{Br} \mathrm{J}$ Clin Pharmacol. 1982;13:665-673.

55. Schottenfeld RS, Pakes J, O'Connor P, Chawarski M, Oliveto A, Kosten TR. Thriceweekly versus daily buprenorphine maintenance. Biol Psychiatry. 2000;47:1072-1079.

56. van Dorp E, Yassen A, Sarton E, Romberg R, Olofsen E, Teppema L, et al. Naloxone reversal of buprenorphine-induced respiratory depression. Anesthesiology. 2006;105:51-57.

57. Pike VW. Considerations in the Development of Reversibly Binding PET Radioligands for Brain Imaging. Curr Med Chem. 2016;23:1818-1869.

58. Tournier N, Comtat C, Lebon V, Gennisson J-L. Challenges and Perspectives of the Hybridization of PET with Functional MRI or Ultrasound for Neuroimaging. 


$\begin{array}{lllll}1 & \text { Neuroscience. } & 2020 . & \text { October } \\ 2 & \text { https://doi.org/10.1016/j.neuroscience.2020.10.015. } & \\ 3 & 59 . & \text { Sander CY, Hansen HD, Wey H-Y. Advances in simultaneous PET/MR for imaging } \\ 4 & & \text { neuroreceptor function. J Cereb Blood Flow Metab. 2020:271678X20910038. } \\ 5 & \text { 60. Seah S, Asad ABA, Baumgartner R, Feng D, Williams DS, Manigbas E, et al. } \\ 6 & & \text { Investigation of cross-species translatability of pharmacological MRI in awake } \\ 7 & & & \\ 8 & \text { nonhuman primate - a buprenorphine challenge study. PloS One. 2014;9:e110432. }\end{array}$


Figures legends

Fig. 1. Impact of selected opioid antagonists on the regional binding of ${ }^{11} \mathrm{C}$ buprenorphine in vivo in rats. PET acquisitions were performed without (baseline) or after pharmacological blocking conditions using the non-selective OR antagonist naloxone (1 $\mathrm{mg} / \mathrm{kg}$ i.v., $5 \mathrm{~min}$ before PET), the selective $\mu$-OR antagonist naloxonazine (10 $\mathrm{mg} / \mathrm{kg}$ i.v., 5 min before PET), the selective $\kappa-O R$ antagonist norbinaltorphimine $(10 \mathrm{mg} / \mathrm{kg}$ i.v., $30 \mathrm{~min}$ before PET) and the selective $\delta$-OR antagonist natrindole ( $3 \mathrm{mg} / \mathrm{kg}$ i.v., $5 \mathrm{~min}$ before PET). Representative summed PET images (40-60min) obtained in each condition and coregistered to a rat brain template are shown in $A$. Uptake ratios (region/cerebellum, mean $\pm S . D, n=4)$ are shown in $B .{ }^{* *} p<0.001$ compared with baseline, $n s=$ non-significant.

Fig. 2. Parametric PET data of ${ }^{11} \mathrm{C}$-buprenorphine obtained from the co-injection study in macaques. Representative parametric images expressed in $V_{T}(A)$. Regional $V_{T}$ measured using the Logan plot analysis for each investigated brain region and each co-injected dose of unlabeled buprenorphine (B). Data are shown as mean $\pm S D, n=4) .{ }^{* * *} p<0.001$ compared with microdose, $n s=$ non-significant.

Fig. 3. Correlation between ${ }^{11} \mathrm{C}$-buprenorphine $V_{\mathrm{T}}$ measured during the co-injection study and the corresponding microdose ${ }^{11} \mathrm{C}$-buprenorphine $V_{\mathrm{T}}$ in macaques. Data are represented as mean $\pm S D$. The slope of each correlation is indicated in the right panel.

Fig. 4. Correlation of outcome parameters derived from the kinetic modeling of ${ }^{11} \mathrm{C}$ buprenorphine PET data obtained in macaques using microdose or therapeutic dose of buprenorphine. Correlation between the binding potential $\left(\mathrm{BP}_{\mathrm{p} \text {;microdose }}\right)$ and the total volume of distribution $\left(V_{\mathrm{T} \text {;microdose }}\right)$ of microdose ${ }^{11} \mathrm{C}$-buprenorphine is shown in $\mathrm{A}$. Correlation of ${ }^{11} \mathrm{C}$-buprenorphine distribution volume ratio (DVR, Logan reference method) estimated in microdose experiments $\left(D V R_{\text {microdose}}\right)$ and $D V R$ obtained after co-injection with unlabeled buprenorphine $\left(D V R_{0.003 \mathrm{mg} / \mathrm{kg}}\right)$ is reported in $B$. Difference between $D V R_{\text {microdose }}$ and $D V R_{0.003 \mathrm{mg} / \mathrm{kg}}$ was not significant (paired $t$-test). Correlation of either $D V R_{\text {microdose }}$ or $\mathrm{DVR}_{0.003 \mathrm{mg} / \mathrm{kg}}$ with $\mathrm{BP}_{\mathrm{p} \text {;microdose }}$ are shown in $\mathrm{C}$ and $\mathrm{D}$, respectively. The coefficient of determination $\left(R^{2}\right)$ is reported for the correlation of outcome parameters estimated in brain regions

of each individual. 
Tables

Table 1. Outcome parameters obtained with PET pharmacokinetic modeling and in vivo binding experiments in macaques.

\begin{tabular}{|c|c|c|c|c|c|c|c|c|c|c|c|c|}
\hline \multirow[t]{2}{*}{ Brain region } & \multirow{2}{*}{$\begin{array}{c}\boldsymbol{V}_{\mathrm{ND}, \text { saturation }} \\
\left(=V_{\mathrm{T}, 0.11}\right. \\
\mathrm{mg} / \mathrm{kg})\end{array}$} & \multirow[t]{2}{*}{$V_{\mathrm{ND}, \text { graphical }}$} & \multirow[t]{2}{*}{$\mathrm{BP}_{\mathrm{p}, \text { microdose }}$} & \multirow{2}{*}{$\begin{array}{l}\text { DVR } \\
\text { se }\end{array}$} & \multirow[t]{2}{*}{ DVR $0.003 \mathrm{mg} / \mathrm{kg}$} & \multicolumn{6}{|c|}{$\begin{array}{l}\text { Estimated receptor occupancy (\%) associated with } \\
\text { plasma levels of buprenorphine }\end{array}$} & \multirow{2}{*}{$E C_{50}(\mu \mathrm{g} / \mathrm{L})$} \\
\hline & & & & & & $0.3 \mu \mathrm{g} / \mathrm{L}$ & $0.6 \mu \mathrm{g} / \mathrm{L}$ & $1 \mu \mathrm{g} / \mathrm{L}$ & $3 \mu \mathrm{g} / \mathrm{L}$ & $6 \mu \mathrm{g} / \mathrm{L}$ & $9 \mu \mathrm{g} / \mathrm{L}$ & \\
\hline Frontal cortex & $3.62 \pm 0.68$ & $3.44 \pm 1.70$ & $4.80 \pm 0.75$ & $1.40 \pm 0.19$ & $1.47 \pm 0.11$ & 33.2 & 49.7 & 62.1 & 82.7 & 90.2 & 93.1 & $\begin{array}{l}0.60(0.07 \text { to } \\
1.12)\end{array}$ \\
\hline Orbital cortex & $3.56 \pm 0.78$ & $3.42 \pm 1.33$ & $4.01 \pm 0.66$ & $1.22 \pm 0.15$ & $1.39 \pm 0.09$ & 27.4 & 43.1 & 55.8 & 79.1 & 88.3 & 91.9 & $\begin{array}{l}0.79(0.30 \text { to } \\
1.30)\end{array}$ \\
\hline $\begin{array}{c}\text { Cingulate } \\
\text { cortex }\end{array}$ & $3.77 \pm 0.70$ & $3.60 \pm 1.78$ & $5.48 \pm 1.03$ & $1.50 \pm 0.28$ & $1.67 \pm 0.19$ & 29.4 & 45.5 & 58.1 & 80.6 & 89.3 & 92.6 & $\begin{array}{c}0.72(0.33 \text { to } \\
1.11)\end{array}$ \\
\hline $\begin{array}{l}\text { Temporal } \\
\text { cortex }\end{array}$ & $3.67 \pm 0.75$ & $3.46 \pm 2.13$ & $3.88 \pm 0.83$ & $1.26 \pm 0.15$ & $1.41 \pm 0.05$ & 31.0 & 47.4 & 60.0 & 81.8 & 90 & 93.1 & $\begin{array}{c}0.67(0.18 \text { to } \\
1.15)\end{array}$ \\
\hline Parietal cortex & $3.57 \pm 0.63$ & $3.41 \pm 1.80$ & $4.48 \pm 1.05$ & $1.37 \pm 0.13$ & $1.40 \pm 0.10$ & 34.3 & 51.1 & 63.5 & 83.9 & 91.3 & 94 & $\begin{array}{l}0.58(0.20 \text { to } \\
0.95)\end{array}$ \\
\hline Occipital cortex & $2.93 \pm 0.62$ & $2.84 \pm 2.29$ & $2.42 \pm 1.05$ & $N A$ & $N A$ & $T$ & $\bar{\dagger}$ & $\dagger$ & $T$ & $\bar{\dagger}$ & 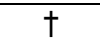 & $\dagger$ \\
\hline Caudate & $4.11 \pm 0.56$ & $3.91 \pm 1.80$ & $5.82 \pm 1.39$ & $1.57 \pm 0.31$ & $1.8 \pm 0.25$ & 23.6 & 38.3 & 50.8 & 75.6 & 86.1 & 90.3 & $\begin{array}{c}0.99(0.43 \text { to } \\
1.50)\end{array}$ \\
\hline Putamen & $4.42 \pm 0.79$ & $4.21 \pm 1.83$ & $6.41 \pm 1.44$ & $1.71 \pm 0.31$ & $1.9 \pm 0.21$ & 28.0 & 43.8 & 56.5 & 79.6 & 88.6 & 92.1 & $\begin{array}{c}0.77(0.34 \text { to } \\
1.20)\end{array}$ \\
\hline Amygdala & $3.92 \pm 0.59$ & $\dagger$ & $4.90 \pm 1.05$ & $1.39 \pm 0.24$ & $1.62 \pm 0.19$ & 14.5 & 25.3 & 36.1 & 62.9 & 77.2 & 83.6 & $\begin{array}{l}1.77(0.60 \text { to } \\
2.94)\end{array}$ \\
\hline Thalamus & $4.61 \pm 0.76$ & $4.33 \pm 1.99$ & $5.17 \pm 0.93$ & $1.54 \pm 0.27$ & $1.77 \pm 0.19$ & 23.4 & 37.9 & 50.4 & 75.3 & 85.9 & 90.1 & $\begin{array}{c}0.98(0.33 \text { to } \\
1.64)\end{array}$ \\
\hline Hypothalamus & $3.85 \pm 0.70$ & $\dagger$ & $4.38 \pm 0.79$ & $1.27 \pm 0.17$ & $1.55 \pm 0.08$ & 23.4 & 37.9 & 50.4 & 75.3 & 85.9 & 90.1 & $\begin{array}{c}0.98(0.22 \text { to } \\
1.74)\end{array}$ \\
\hline Cerebellum & $3.55 \pm 0.70$ & $3.43 \pm 2.13$ & $2.21 \pm 0.93$ & $1.06 \pm 0.12$ & $1.11 \pm 0.05$ & $\dagger$ & $\dagger$ & $\dagger$ & $\dagger$ & $\dagger$ & $\dagger$ & $\dagger$ \\
\hline
\end{tabular}

$V_{\mathrm{ND}}$ is the non-displaceable volume of distribution. $V_{\mathrm{ND} \text {,saturation }}$ has been estimated using the Logan plot method and the maximum co-injected

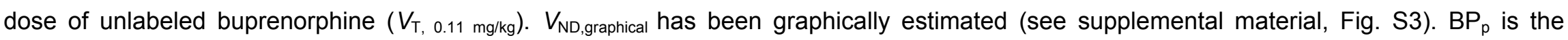
binding potential relative to the plasma kinetic of ${ }^{11} \mathrm{C}$-buprenorphine. DVR is the distribution volume ratio estimated with the Logan reference method using the occipital cortex as the pseudo-reference region. $\mathrm{EC}_{50}$ is the estimated plasma concentration of buprenorphine associated to 
$50 \%$ of buprenorphine brain receptor occupancy. $N A=$ non-applicable, $\dagger=$ poorly estimated. Data are expressed as mean (receptor occupancy) or mean $\pm \mathrm{SD}$. Estimated $\mathrm{EC}_{50}$ are reported as mean (confidence interval $95 \%$ ). 
Figures

2

$3 \quad$ Figure. 1
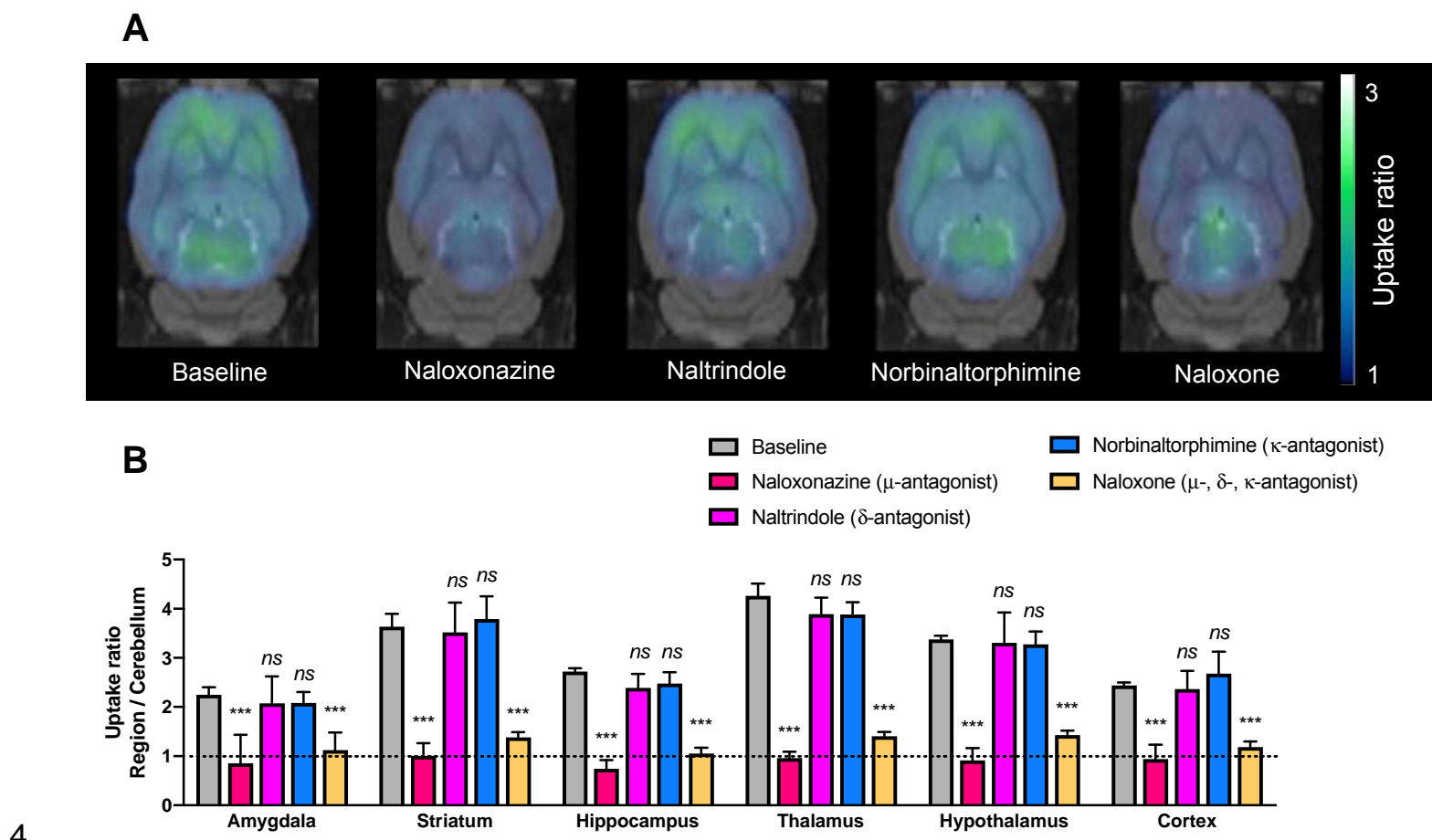

5 

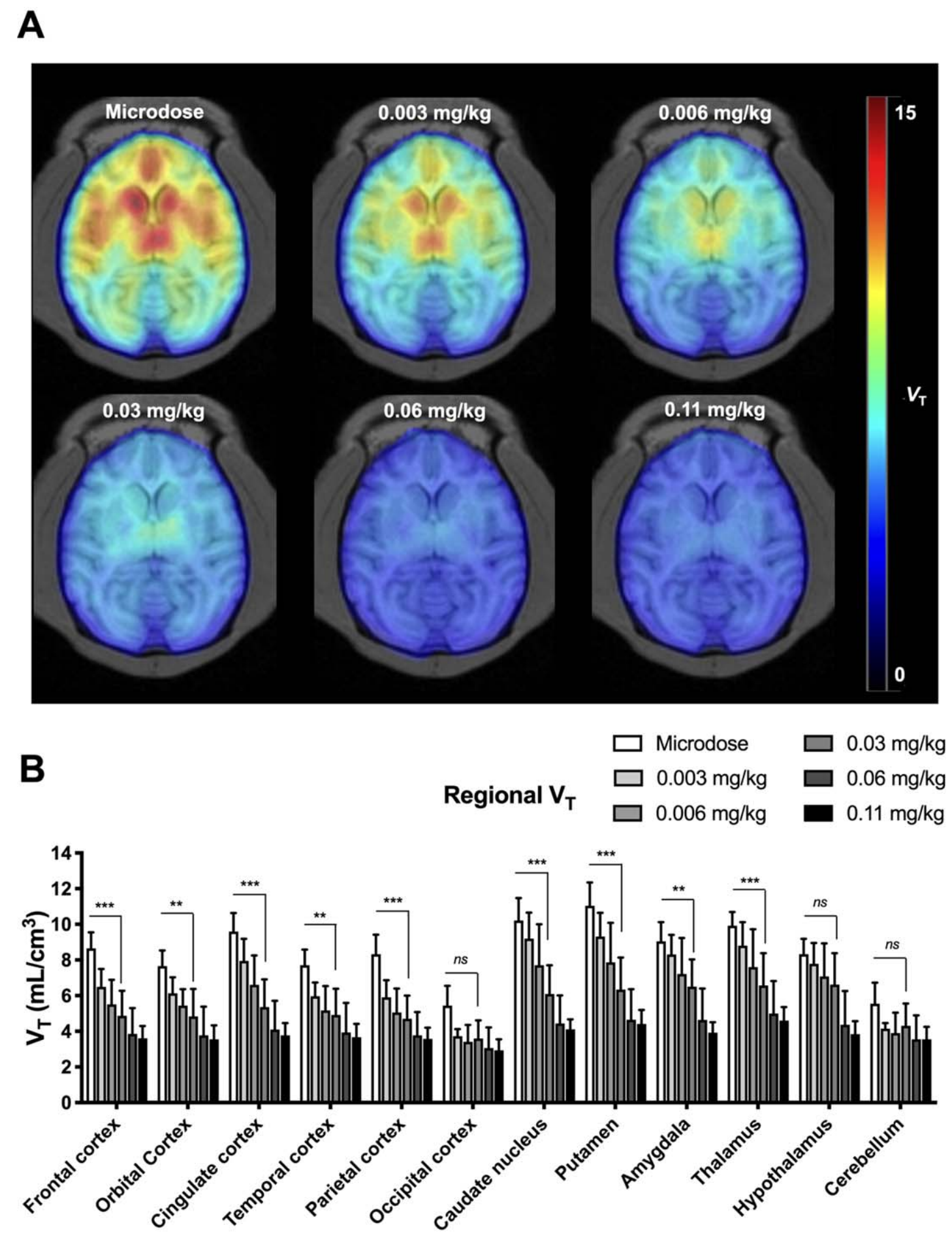
1

2

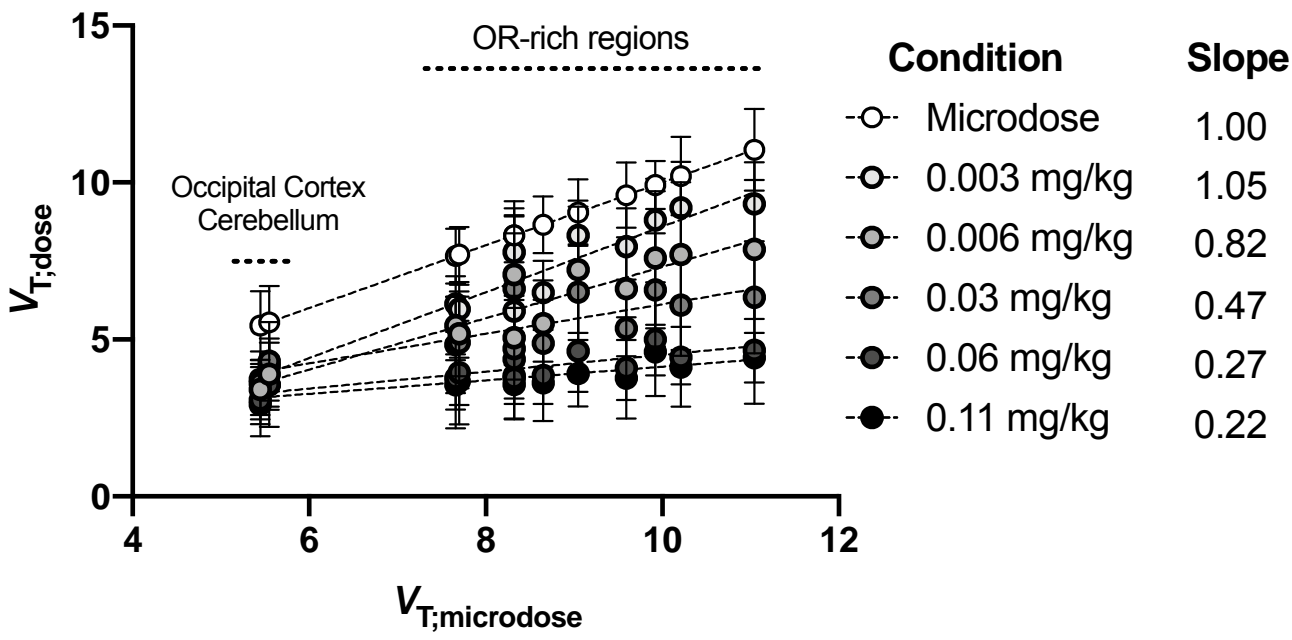

4 
Figure 4

A
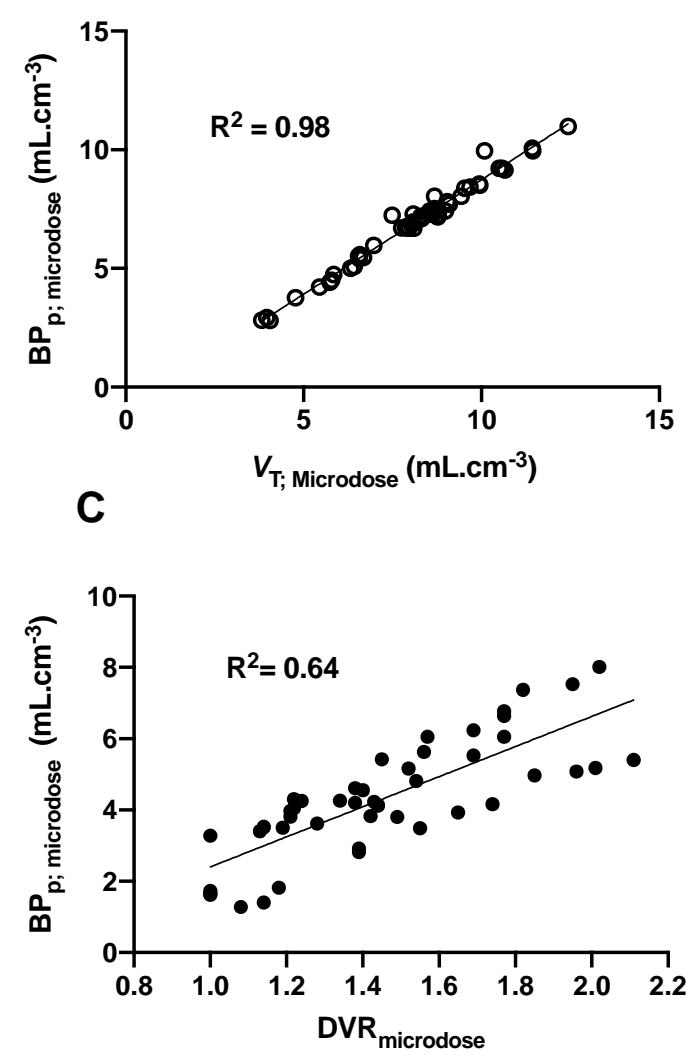

B
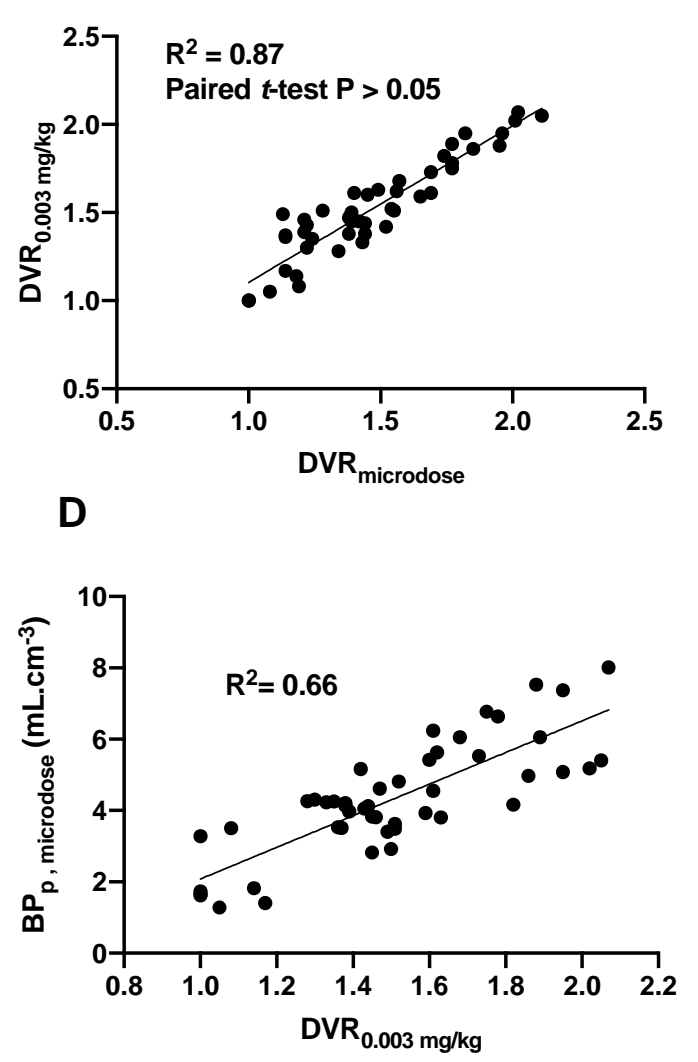


\section{A}

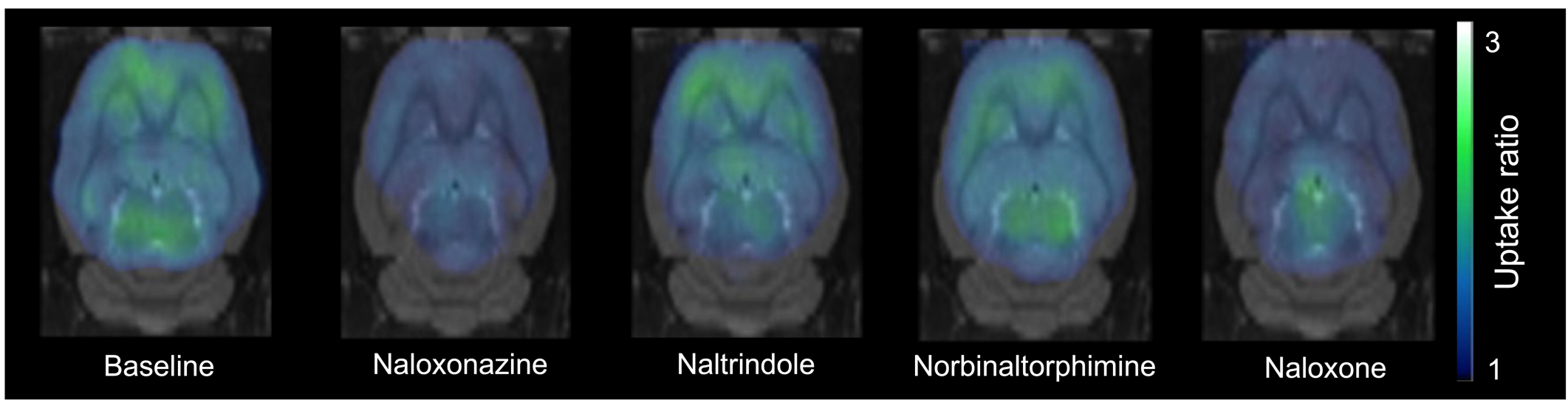

\section{B}

$\square$ Baseline

$\square$ Naloxonazine ( $\mu$-antagonist)

Naltrindole ( $\delta$-antagonist)

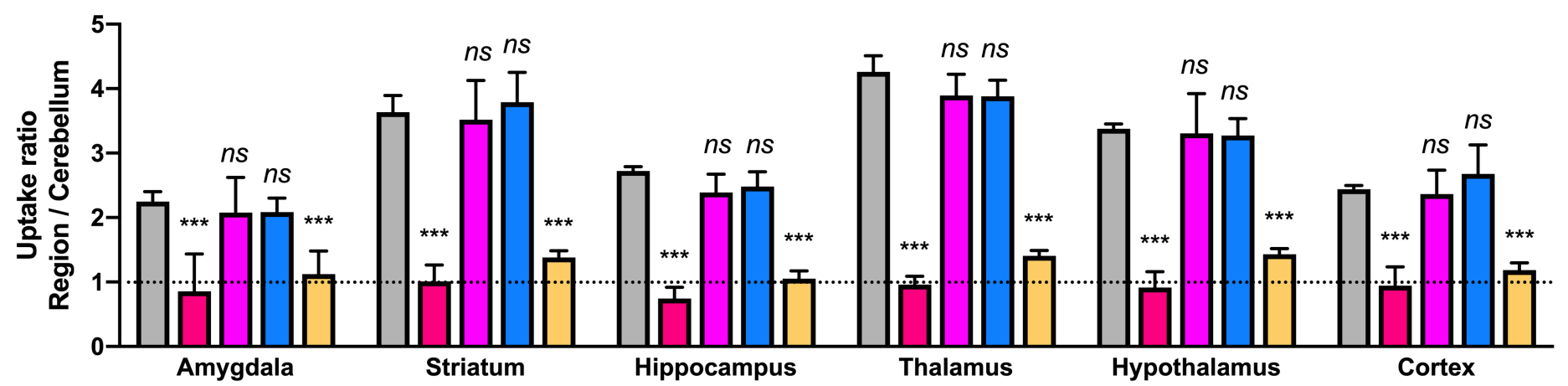




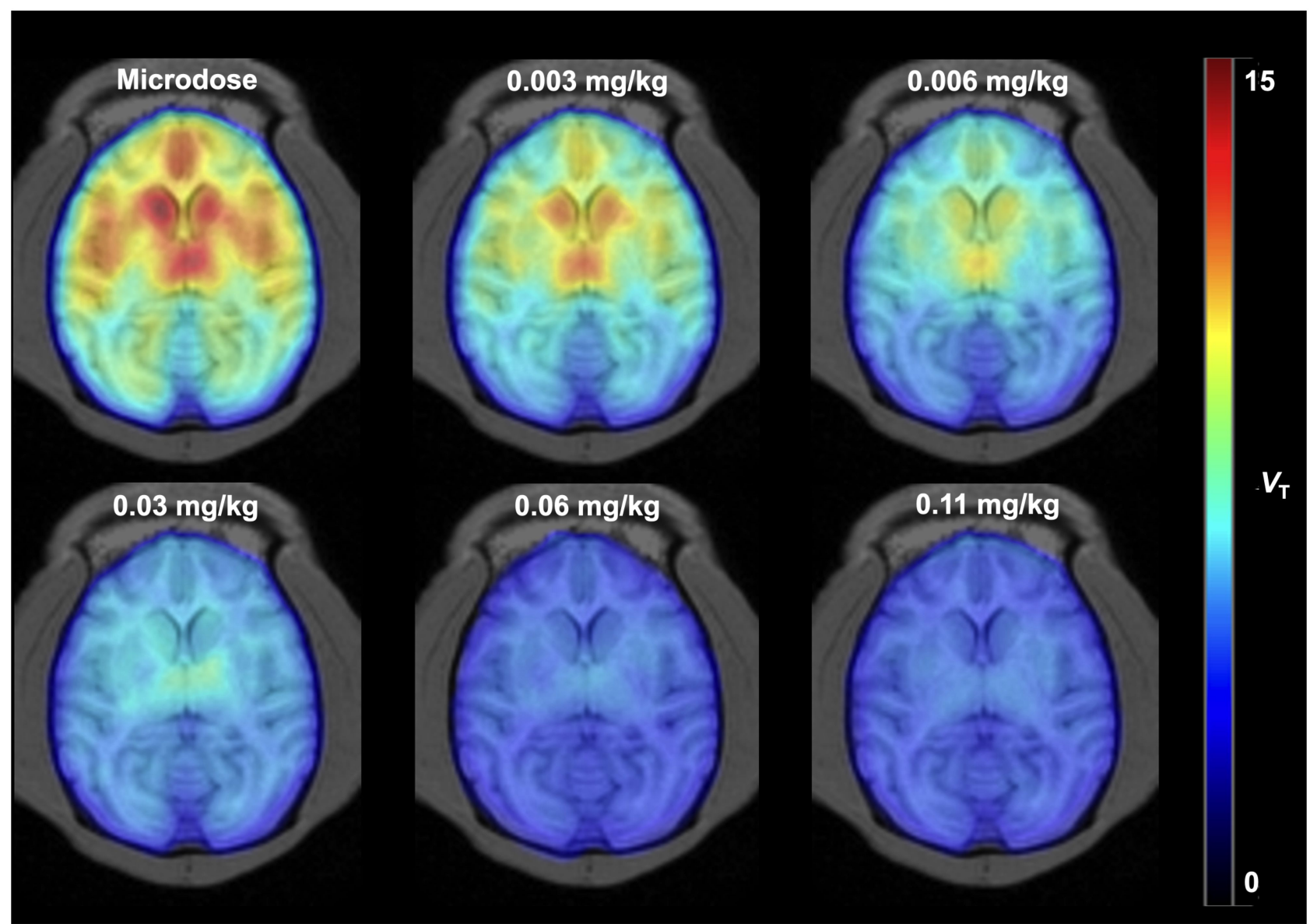

B
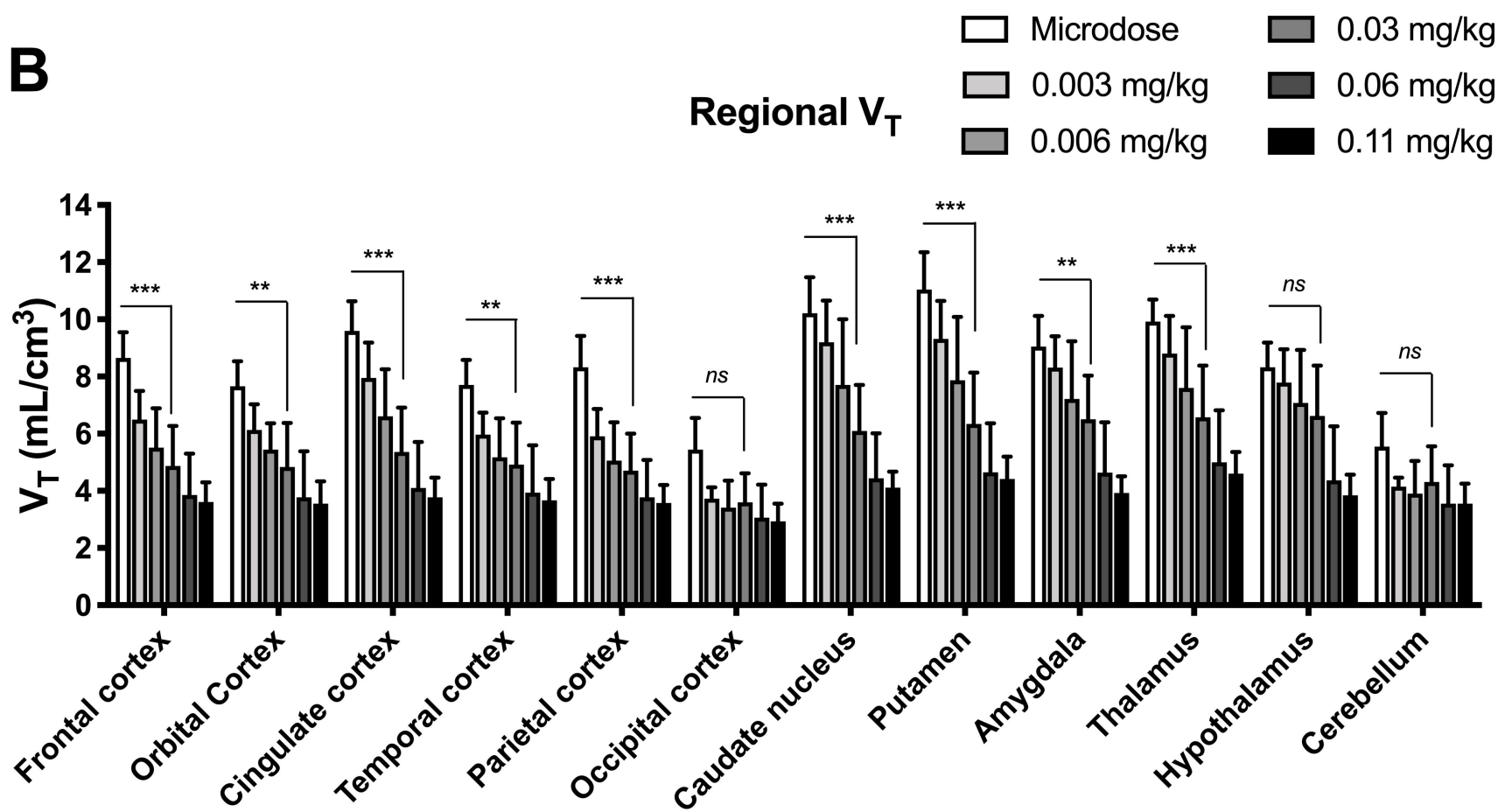


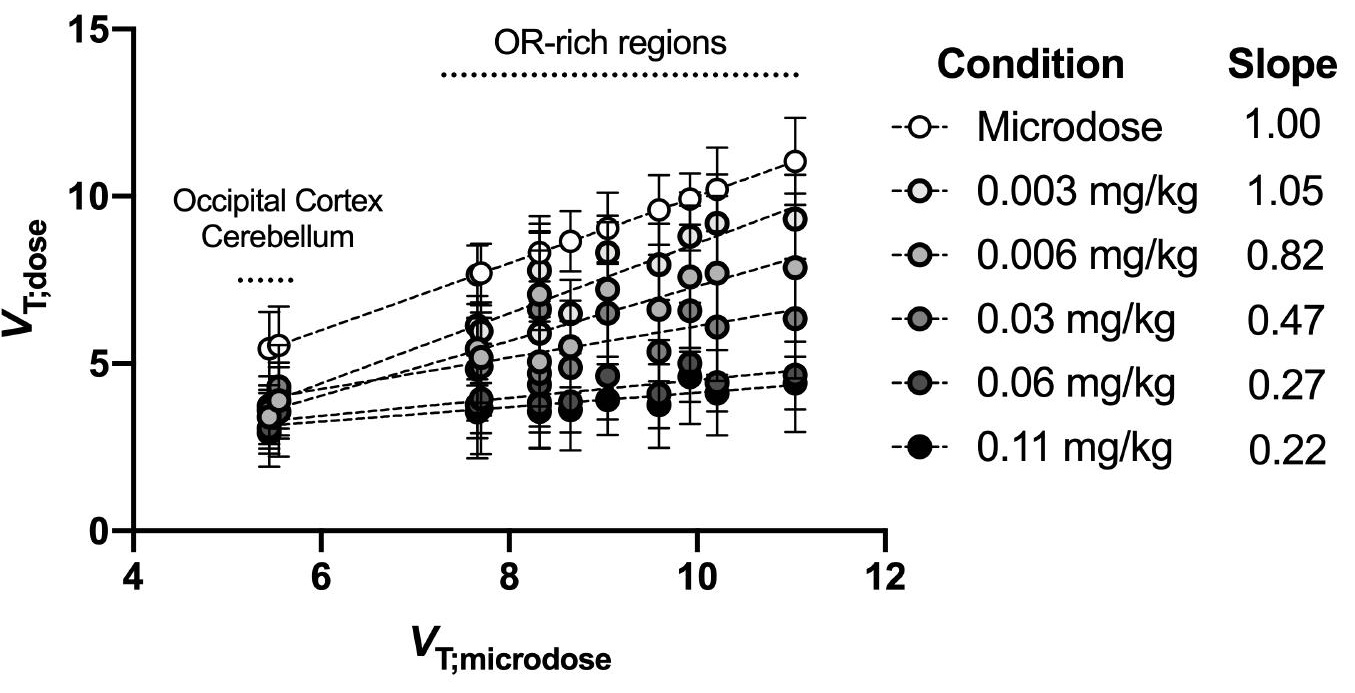




\section{A}
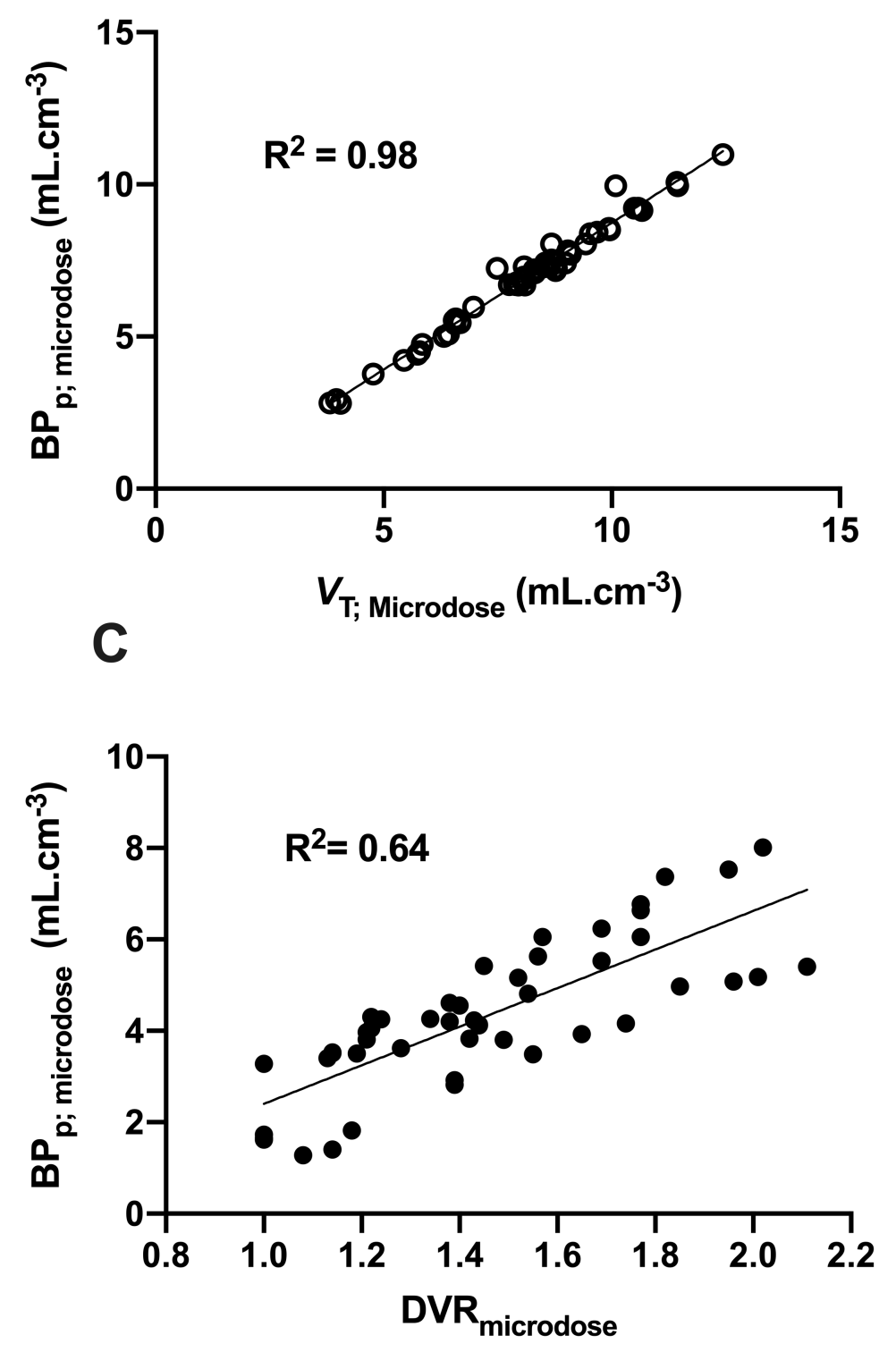

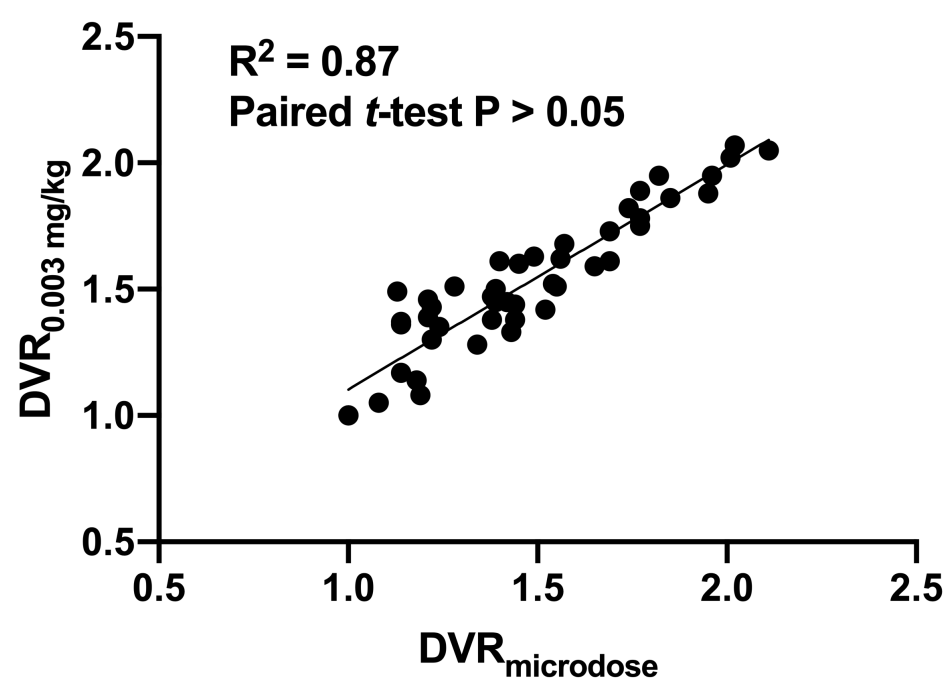

D

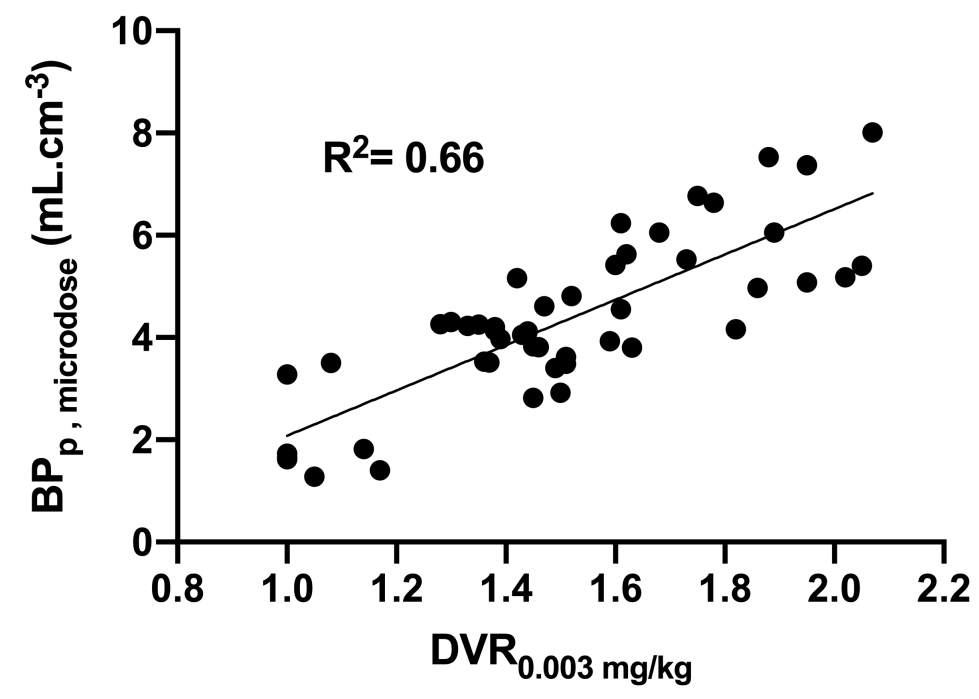

